\title{
O ART. 9 DO CODIGO CIVIL EM FACE DO ART. 108 DA CONSTITUIÇÃO DE 34
}

Antonio Miguel Leão Bruno

These apresentada em 31 -V-1935 ao Exmo. Snr. Professor Doutor HONORIO FERNANDES MONTEIRO

Lente Cathedratico da Faculdade de Direito da Unlversidado de São Paulo 


\section{TOMO PRIMEIRO}




\section{S U M M A R I O}

\section{Tomo Primeiro:}

Prefacio do Professor Doutor Honorio FeRnandes Monteiro ... 201 $\operatorname{Preambulo} \ldots \ldots \ldots \ldots \ldots \ldots \ldots \ldots$

\section{A THEORIA.}

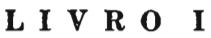

ORIGEM HISTORICA DO ARTIGO 108 DA CONSTITUIÇÃO DE 34 E DO ARTIGO 9 DO CODIGO CIVIL BRASILEIRO

CAP. I - O artigo 108 da Constituição de 34
1. Fontes 215

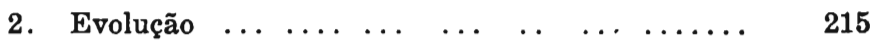
3. Redacção final $\ldots \ldots \ldots \ldots \ldots$

CAP. II - 0 artigo 9 do Codigo Civil Brasileiro

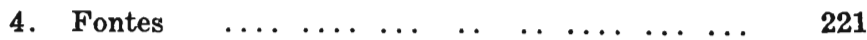

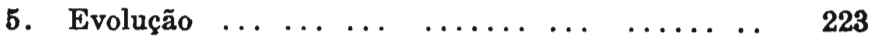

6. Redacção do art. 9 do Codigo Civil de 1-1-1916 .. 224

7. Redacção actual $\ldots \ldots \ldots \ldots \ldots$

C.AP. III - Na Assembléa Nacional Constituinte de 34

8. Fechando este Livro I ................ 229 


\section{I V R O I I}

\section{AS DUAS INTERPRETAÇÕES}

CaP. I - 0 artigo 9 do Codigo Civil estaria abrogado.

9. A Constituição actual e a materia de direito civil

10. O Sentir do Professor Doutor Clovis Beviraqua

11. O Sentir do Professor Doutor Jorge Americano

CAP. II - A interpretação contrária

12. O Sentir do P'rofessor Doutor Francisco Morato

13. O Sentir do Professor Doutor SAMpaio Doria

14. O Sentir do Professor Doutor WaldemaR

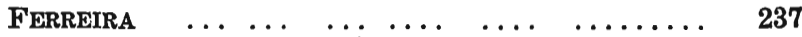

15. O Sentir do Professor Doutor Azevedo MARques

\section{I V R $\quad$ O $\quad$ I I I}

\section{CAPACIDADE CIVIL E CAPACIDADE CIVICA OU POLITICA}

CAP. I - $O$ que se entende por capacidade civil

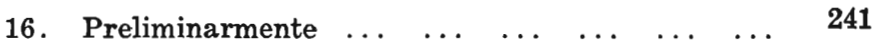

17. Pessôa - Personalidade - Capacidade 241

18. Capacidade civil .. ... ....... ... ... 244

19. Direitos civis ... $\ldots$.. .

CAP. II - 0 que se entende por capacidade civica ou politica

20. Capacidade civica ou politica ... ... .. 252

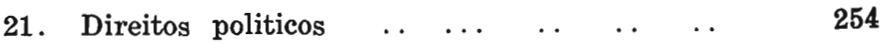

\section{I V R O I V}

O ART. 9 DO CODIGO CIVIL EM FACE DO ART. 108 DA CONSTITUIÇÃO DE 34

CAP. I - Applicação das leis

22. Os dois campos $\ldots \ldots \ldots \ldots \ldots \ldots \ldots \ldots$

23. A intenção do Legislador $\ldots \ldots \ldots \ldots \ldots \ldots$ 
24. O fim social da Lei $\ldots \ldots \ldots \ldots \ldots \ldots$

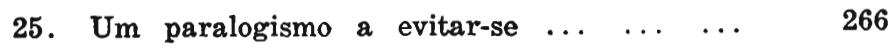

CAP. II - A solução

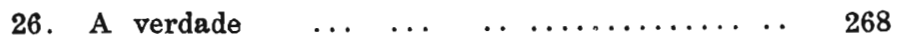

27. 0 art. 9 do Codigo Civil Brasileiro não foi revogado pelo art. 108 da Constituição de $34 \quad 269$

\section{Tomo Segundo:}

\section{.E A PRATICA}

Duas palavras ...

L I V R O V

APPLICAÇõES PRATICAS

Uma advertencia

CAP. I - Applicações no Direito Civil

$\begin{array}{lllllllllll}\text { Applicação } & n & 1 & \ldots & \ldots & \ldots & \ldots & \ldots & \ldots & \ldots & \ldots\end{array}$

CAP. II - Applicações no Direito Commercial

$\begin{array}{llllllllllll}\text { Applicação } & n \cdot{ }^{0} & 2 & \ldots & \ldots & \ldots & \ldots & \ldots & \ldots & \ldots & & 288\end{array}$

$\begin{array}{lllllllllll}\text { Applicação } & n .0^{\circ} & 3 & \ldots & \ldots & \ldots & \ldots & \ldots & \ldots & \ldots & 292\end{array}$

CAP. III - Applicações no Direito Penal

$\begin{array}{llllllllll}\text { Applicąão n. } & 4 & \ldots & \ldots & \ldots \ldots \ldots & \ldots & \ldots & \ldots & 296\end{array}$

$\begin{array}{llllllllllll}\text { Applicação } & \text { n. } & 5 & \ldots & \ldots & \ldots & \ldots & \ldots & \ldots & \ldots & 300\end{array}$

$A N$ N $\mathrm{X}$ O $\mathrm{S}$

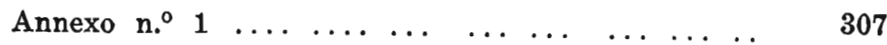

Annexo n. ${ }^{\circ} 2$

$\begin{array}{lllllllllllll}\text { Annexo } & n \cdot 0^{\circ} & 3 & \ldots & \ldots & \ldots & \ldots & \ldots & \ldots & \ldots & \ldots & 317\end{array}$

$\begin{array}{lllllllllll}\text { Annexo } & 0^{\circ} & 4 & \ldots & \ldots & \ldots & \ldots & \ldots & \ldots & \ldots & \end{array}$

TRABALHO DE SEMINARIO. 323 
António Miguel Leão Bruno sempre foi ótimo estudante. No Ginásio do Estado da Capital foi o primeiro aluno de sua turma, titular em 1922 do prémio António de Godoi. Na Faculdade de Medicina de São Paulo, por onde é formado, deu sobejas provas de sua dedicação, conquistando as melhores notas. Na Faculdade de Direito, colocou-se, desde logo, entre os primeiros estudantes.

Em 1935 regiamos, no $4 .^{\circ}$ ano, a cadeira de Direito Comercial e, designado pela Congregação, a cadeira de Direito Civil. A esse tempo, como repontasse o problema da conciliação entre o art. 9 do Código Civil e o art. 108 da Constituição Federal de 1934, nós o escolhemos para trabalho de seminário.

Entregamos a solução do problema aos alunos prestando-lhes, apenas, informes bibliográficos $e$ guiando-os, aqui e ali, na interpretação desta ou daquela lição dos autores, sem, porém, sugerir conclusões, forçando, deste modo, o hábito do trabalhn independente e a produção de alguma cousa de pessoal.

Recebendo algumas dezenas de trabalhos, reunidos seus autores, á noite, em sala da Faculda- 
de, ai, sob nossa presidencia, depois de classificar os trabalhos pelas conclusões, convidamos seus autores a sustentá-los. Com isto, quizemos, além do trabalho de seminário, iniciar os alunos na util tarefa da sustentação oral, e conduzir todos á solução verdadeira da tese proposta.

o resultado desse convívio, que tanta satisfação moral nos proporcionou, temo-lo na monografia de António Miguel Leão Bruno, o melhor trabalho apresentado e que, depois de examinado pelos professores Spencer Vampré, Gabriel de Rezende Filho $e$ Sebastião Soares de Faria, é publicado na Revista da Faculdade, como distinção ao bom estudante, conforme proposta do saudoso Prof. Rafael Sampáio e minha, aprovada pela Congregação.

Se ao trabalho - que é de estudante - faltassem outros méritos, bastar-lhe-ia, a nosso ver, o de ter aportado ás mesmas conclusões consagradas pela doutrina e pela jurisprudência quando, muito posteriormente, consideraram o assunto. 


\section{P R E A M B U L O}

Preambulo cumpre.

Que não se vislumbre em nossa intenção, nesta breve noticia explicativa, pretendermos de materia outra nos occupar que não a que nos propuzemos.

$E^{\prime}$ que ao encetarmos este trabalho, esperançosos, julgamos de direito e dever - levantar bem alto o nosso espirito e volver os nossos olhos para os principaes factores e fautores do renascimento do ensino superior em o nosso Estado e em uma hora tão opportuna, após ter baixado "tanto o nivel do ensino superior e secundario em nosso pais, devido ás medidas de desmoralização de um e de outro, provindas das autoridades superiores, emanadas do poder legislativo, que a Segunda Constituinte Republicana tomou sobre si a missão de impedir o desenvolvimento da avalanche. "(1)

$E$ ' de crises e derrocadas o periodo que atravessamos, - dizia ha tempos grande jurisconsulto e erudito professor de Direito Judiciario da nossa Faculdade de Direito - em contraste com o progresso vertiginoso das industrias e sciencias. Por toda parte o estiolamento dos preceitos de civismo, de decencia, de moralidade $e$ de religião, repercutindo molestamente na politica, na familia e na sociedade; por toda parte o predominio do

(1) Professor Doutor Waldemar Ferreira: Entrevista ao Diario de São Paulo, transcripta "in" Revista da Faculdade de Direito de São Paulo, Vol. XXX, F. IV, pag. 789. 
sensualismo, as jactancias da frivolidade, a supremacia das incompetencias, o imperio da cobiça, as reivindicações do egualitarismo, as audacias do sovietismo e a soberania da vida accomodaticia, tudo em revolta permanente contra as leis da ordem divina e humana. (2)

Foi justamente quando mais se sentia necessaria que se deu a feliz intervenção do nosso patriotico governo. "Nesta época rudemente trabalhada por duas correntes sociaes e politicas que, fazendo appello á força, á vontade e á acção, tendem a esmagar a intelligencia e a liberdade sob o rolo compressor da machina do Estado, o governo de São Paulo criou a Universidade, como um protesto e affirmação de fé na liberdade de pensamento $e$ de investigação, de critica e de debate, que constitue os fundamentos das instituições democraticas e universitarias. E' a resposta de S. Paulo aos ideaes da força e da violencia. A criaça da Universidade importa, de facto, pela propria natureza e finalidade destas instituiçôes, numa declaração de principios, segundo os quaes se substitue a ordem da força pela ordem do pensamento; a violencia que corta as discussões pela liberdade que as estimula; a obstinação que geram os preconceitos pela tolerancia que é inherente ao proprio espirito scientifico. $E$ ' na Universidade que se podem plasmar homens $e$ ideaes capazes de resguardar, dos perigos que as ameaçam por todos os lados, a democracia e a sciencia, a autoridade e a liberdade, e de oppôr um systema democratico de selecção e utilisação necessaria das capacidades recrutadas em todas as camadas sociaes, a todo systema demagogico que, tendendo ao nivelamento dos bens e dos individuos, tende a rebaixar aquelle que póde mais $e$ a

(2) Professor Doutor Francisco Morato: "A missão do homem do direito", "in" Revista da Faculdade de Direito de São Paulo, Vol. XXX, F. IV. 1934, pag. 670. 
paralysar, em consequencia, o esforço, a criação e a vida." (3)

Caracteristica principal das Universidades, por toda parte, é "o espirito scientifico de pesquisa", "id est" a indagação completamente objectiva e livre de quaesquer considerações que não sejam a busca da verdade, e que só se criará pelo estudo e pela pesquisa da sciencia pura.

Realmente, por toda parte, - ensina MAURICE CRoISET, "as conquistas realizadas sobre o desconhecido pelo espirito humano são incessantes e admiraveis, mas yor toda parte ellas se revelam, como incompletas e provisorias. Não nos lamentemos, porém. $E$ ' este mesmo defeito que é o estimulante da intelligencia. Toda descoberta abre uma perspectiva; toda solução põe um problema. O que se chama a "sciencia já feita" tem incontestavelmente um immenso valor, tanto por suas applicações quanto como materia de ensino; mas, de um ponto de vista superior, não é, afinal, senão um caminho aberto, um meio de ir mais longe. "A sciencia verdadeira é a pesquisa." A maior parte dos investigadores foram homens mais ou menos desprendidos das coisas exteriores, estranhos de algum modo aos ruidos de fóra. A pesquisa é uma paixão, ou não existe. Ella toma um honem e o quer todo inteiro"

Charles RicheT, o grande physiologista contempo. raneo, diz-nos a este respeito, que para ser um sabio é preciso ser revolucionario, isto é, tratar pela duvida methodica as theorias classicas mais classicas, tudo discutir, tudo aprofundar. "Um dos privilegios da sciencia é que ella nos traz o imprevisto. O "já visto" é insup. portavel; e a sciencia, com as.suas descobertas que são

(3) Doutor FrRnando de Azevedo: Pela Universidade de São Paulo, Conferencia pronunciada, a 4 de janeiro de 1935, na sessão solenne de encerramento dos cursos do Instituto de Educação, da Universidade de São Paulo. 
revelações, é a unica capaz de pôr alguma coisa de novo em nossa vida" (4).

A principal funcção da Universidade é, pois, cooperar para o aperfeiçoamento do saber humano; mas se assim é, "se a sciencia, longe de se fixar com os sabios num molde immutavel e impeccavel, é feita de imprevisto, e se é proprio do professor universitario não só transmittir a "sciencia feita", mas esforçar-se por concorrer para a "sciencia a fazer-se", a se constituir; a pesquisa scientifica, que é o estudo dos factos e a reflexão sobre elles, é o unico meio que tem o professor de penetrar no futuro e a elle cabe, como dever primordial cultivar e despertar, nos seus discipulos, o espirito de pesquisa $e$ de invenção.

"Os trabalhos de laboratorio e de seminario, as investigações e os inqueritos devem, pois, preponderar no plano das actividades universitarias, para que o gosto $e$ os methodos de observação, de experimentação e de descoberta scientifica se installem na vida normal da Universidade; nella se forme um grupo de iniciadores e de mestres em todos os ramos de estudos, e se desenvolva um espirito commum de pesquisa livre e desinteressada e de cooperação incessante, com a qual se possa manter, através de todos os obstaculos e das differenças individuaes de caracteres e de opiniōes, uma solidariedade profunda $e$ irreductivel entre os seus membros. Se ao Estado que instituin a Universidade, compete apparelhal-a cada vez mais de laboratorios, observatorios e bibliothecas especiaes $e$ encorajar largamente, por todos os meios, a pesquisa e a descoberta, para que ella se torne um verdadeiro centro de altos estudos, dedicado ao progresso das sciencias; não é menor, na ordem moral, a parte que resta aos professores, para despertar, nos discipulos, o espirito scientifico que é curiosidade e gosto de investigação e dar-lhes, com a disciplina ascetica dos methodos scientificos, os meios de satisfazel-os" (5).

(4) Doutor Fernando de Azevedo: Conf. e loc. cits.

(5) Id., Id., Id. 
Bem comprehenderam e comprehendem as idéas scientificas acima os dirigentes de nossa Faculdade de Direito - e prova frizante disso é a construcção do novo edificio da Faculdade e o especial carinho que mereceu a installação e organização de sua velha e importantissima bibliotheca (6) estimulando dest'arte os estudos; bem comprehenderam e comprehendem $-e$ melhor de quem quer que seja - todos os insignes professores dessa tradicional Casa de ensino superior, que, de accordo com o conceito moderno de Universidade, mesmo as escolas profissionaes superiores devem ser institutos de altos estudos.

Já em os nossos tres primeiros annos de estudos nesse estabelecimento de ensino - de um modo perfeito haviam nossos preclaros Mestres combinado intimamente a instrucção com a investigação.

Quem, hontem como hoje, ao assistir as proficientes aulas dos professores dessa Faculdade - nellas não vê a relação directa e permanente, por elles estabelecida entre o trabalho de elaboração scientifica ou pesquisas originaes, $e$ o ensino propriamente dito?

Inda não sahida a nossa Carta Magna de 34: quantos e preciosos commentarios nos foram dados em 1933 pelo eminente cathedratico de Direito Constitucional, quantas e interessantes theses. NOVAS foram estudadas e resolvidas por professor e alumnos! (7)

(6) Com seu novo apparelhamento e organização, sob a competente e dedicada chefia technica do exmo. sr. ANTonio Constantino, a Bibliotheca da Faculdade de Direito da Universidade de São Paulo se encontra, hoje em dia, efficientissima para o fim a que se destina.

(7) Pelo preclaro Cathedratico de Direito Constitucional foram, durante o anno lectivo de 1933, pedidas que fossem desenvolvidas pelos srs. alumnos duas theses: 1. Como conciliar o censo alto com o suffragio universal?, que entregámos no $10^{\circ}$ semestre daquelle anno; e, 2. Systemas de eleição presidencial, que apresentámos ao illustre Professor A. DE SAMPaIo DORIA no $2 .^{\circ}$ semestre. 
$E$ em 1934: quantos e recentes problemas de Direito Commercial foram debatidos em aula, quantos'os traba. lhos ORIGINAES apreciados PESSOALMENTE pelos senhores alumnos! (8)

E em 1935: A-pesar de a interpretação da materia civil e commercial dar ensanchas a amarragens aventuro. sas e offerecer muitas duvidas e lacunas.. A-pesar de ella nos expôr a vertiginosas ascenções e a precipicios temerosos: Nas pinturas moveis, nos panoramas sonóros, que a palavra magica dos illustres Mestres fez nascer em nós - a estrada se torna suave, o horizonte $e$ o espaço se alargam formidavelmente, como se, do alto de uma torre, nos elevássemos em velívolo para percorrer um continente e transpôr diversos mares.

Ora, foi seguindo essa orientação altamente scientifica que a presente these nos foi suggerida pelo insigne cathedratico de Direito Commercial da Faculdade de Direito da Universidade de São Paulo, Professor Honorio Fernandes Monteiro.

Puzemos as mãos á obra; mas logo nos achámos embaraçados. Foi então que vimos perfeitamente o interesse dos preclaros Mestres na resolução do thema ern apreço. Assim é que conseguimos, em conversação amistosa, as vistas dos senhores professores: Doutor HoNoRio Monteiro, Doutor Francisco Morato, Doutor A. DE Sampaio Doria, Doutor Waldemar Ferreira, Doutor JoRGe AMERICANo - delles, principalmente do primeiro. a quem quasi que diariamente tomávamos parte de seu precioso tempo, - conseguimos bôa bibliographia e fontes, casos praticos e demais elementos para facilitar a feitura desta monographia.

(8) Ao insigne Professor Wandemar Ferroira apresentámos, no $2 .^{\circ}$ semestre de 1934 , a these $\mathrm{Da}$ autorização marital e sua revogabilidade. 
Quem ao trabalho se der de lêr estas paginas nada mais encontrará do que um pallido reflexo dos ensinamentos de nossos dedicados guias acima. A elles os nossos agradecimentos e admiração.

Contentes seremos de contentar tão eminentes $e$ dignos Mestres - aos quaes vênia pedimos para lhes dedicar este modesto trabalho.

Que este ultimo, seja o incitamento que mova outrem, e que se consiga, como póde ser, o que nós almejámos, $e$ não pudemos.

$\nabla \boldsymbol{A} L E T E$

São Paulo, maio de 1935. 
A THEORIA... 


\section{LIVRO I}

ORIGEM HISTORICA DO ARTIGO 108 DA CONSTITUIÇÃO DE 34 E DO ARTIGO 9 DO CODIGO CIVIL BRASILEIRO 


\title{
CAPITULO I
}

\section{O ARTIGO 108 DA CONSTITUIÇÃO DE 34}

\author{
1. FONTES \\ 2. EVOLUÇÃO \\ 3. REDACÇÃO FINAL
}

1. FONTES - Neste Capitulo I procuraremos mostrar de onde procede, de que modo se elaborou, o que em si contém, como se explica e fundamenta $o$ art. 108 da Carta Magna de julho de 34.

Serviram-lhe, naturalmente, de fontes: $1 .^{\circ} 0$ art. 70 da Constituição de 91 (o qual, por sua vez, se baseára: nos projectos preliminares dos membros da commissão pelo governo provisorio da "1. ${ }^{\text {" }}$ Republica encarregada de preparar a Constituição, nos do mesmo governo - de 22 de junho e de 23 de outubro de 1890 e no parecer e emendas da commissão do congresso constituinte de $1890) ; 2 .^{\circ}$ a) o art. 98 do ante-projecto de Constituição elaborado pela commissão nomeada pelo chefe do governo provisorio da " 2 a" $^{\text {a }}$ Republica; $b$ ) o art. 115 da redacção final do projecto de Constituição, trabalho entregue em 27 de junho de 34, á mesa da Assembléa Nacional Constituinte; c) os discursos nesta Assembléa proferidos em defesa ou impugnação do citado artigo e emendas (VIDE: O QUADRO QUE SE SEGUE E O ANNEXO N. 1).

2. EVOLUÇÃO. - A evolução das idéas que presidiram á elaboração do Cap. 1 do Titulo III da Constituição de 34 (DA DECLARAÇÃO DE DIREITOS), capitulo esse que trata "Dos direitos politicos" - póde muito bem ser percebida pelo quadro já referido (por méra curiosidade ahi incluimos o Cap. VI "Das Eleições" do Titulo IV da Constituição politica do Imperio do Brasil). 
Pela Constituição Imperial eram excluidos de votar nas Assembléas Parochiaes : os menores de 25 annos, nos quaes se não comprelendiam porém os casados, e officiaes militares, que fossem maiores de 21 annos, os Bachareis formados, e Clerigos de Ordens Sacras (Const. Imp., art. 92, §1. ${ }^{\circ}$ ).

Pela Constituição de 91 eram considerados eleitores os cidadãos maiores de 21 annos, que se alistassem na fórma da lei, havendo como excepção as do $\S 10^{\circ}$ do cit. art.

Pelo decreto n. 6 de 19 de novembro de 1889, já o governo provisorio declarára eleitores para as camaras geraes e locaes "todos os cidadãos brasileiros no gozo de seus direitos civis e politicos, sabendo lêr e escrever". Eista extensão do direito de suffragio á generalidade dos cidadãos impunha-se como essencial ao novo regimen politico.

As excepções estabelecidas nos differentes numeros do $\S 1 .^{\circ}$, como fundamento tiveram - a falta de independencia dos exceptuados.

A exclusão dos religiosos de ordens monasticas já a Republica a encontrára (Const. Imp., art. $92 \S 4$ ) (1).

A maioria dos senhores constituintes de 91, apesar da erudita dialectica exhibida em prol da mulher-votante, não teve a mesma attitude desassombrada do congresso constituinte de 33-34, o qual, temor não teve de "arrastar para o turbilhão das paixões politicas a parte serena e angelica do genero humano"

No dia 21 de maio de 1934, por occasião da 148. ${ }^{\text {s }}$ sessão ordinaria da Assembléa Nacional Constituinte de 1933-1934, - foi estudado o problema de se estender o direito de voto aos menores de 21 annos, maiores de 18 annos, - contrariamente ao que dispunha a Constituição de 91. (VIDE ANNEXO N. 1).

Debatida naquelle dia a emenda do sr. Aloysio Filнo foi ella approvada. Ampliava essa emenda o direito de voto não só aos universitarios brasileiros menores de 21 annos e maiores de 18

(1) JoÃo BarbalHo: Constituição Federal Brazileira, Commentarios, Rio de Janeiro, 1902, pags. 290-291. 
annos - mas tambem aos brasileiros em geral de um e outro sexo, maiores de 18 annos e alistados na fórma e sob as condições que a lei havia de determinar (VIDE: "Da acta da 148. ${ }^{a}$ sessão ordinaria da Assembléa Nacional Constituinte" - que no presente trabalho vai transcripta em o ANNEXO n. 1).

3. REDACÇÃo FINAL. - A Constituição óra em vigor determina em o seu artigo 108:

ART. 108 - "São eleitores os brasileiros de um ou de outro sexo, maiores de 18 annos, que se alistarem na fórma da lei.

$\S$ Unico - Não se podem alistar eleitores :

a -.os que não saibam lêr e escrever;

b -- as praças de "pret", salvo os sargentos do Exercito e da Armada e das forças auxiliares do Exercito, bem como os alumnos das escolas militares de ensino superior e os aspirantes a official ;

c - os mendigos;

d - os que estiverem, temporaria ou definitivamente, privados dos direitos politicos. 
CONSTITUIÇão POLITICA DO IMPERIO DO BRASIL

ARTIGO 90. - As nomeaçóes dos deputados e senado-
res para a Assembléa Geral, e dos Membros dos Conselhos Geraes das Provincias, serāo feitas por eleiçōes indirectas, elegendo a massa dos Cida-
dãos activos em Assembléas Parochiaes os Eleitores de Provincia, e estes os Representantes da Nação, e Provincia.

ARTIGO 91. - Têm voto nestas eleiçōes primarias: $10^{\circ}$ ) Os cidadãos brasileiros, que estão no gozo de seus direitos
politicos. $2 .^{\circ}$ ) Os estrangeiros naturalisados.

ARTIGO 92. - São excluidos de votar nas Assembléas Parochiaes: $10^{\circ}$ Os menores comprehendem quas officiaes militares, que forem maiores de 21 annos, os $\mathrm{Ba}$ chareis Formados, e Clerigos de Ordens Sacras. 2.. $)$ Os na companhia de seus pais, salvo se servirem Officios puservir, em cuja classe não enmeiros Caixeiros das casas de commercio, os Criados da Casa Imperial, que não forem de ga fabricas. 4.0) Os Religiosos e quaesquer que vivão em communidade claustral. 5. ${ }^{\circ}$ os que não tiverem de renda liquida annual, cem mil réis por mercio, ou empregos.

ARTIGO 93. - Os que não primarias de Parochia, ña podem ser Membros nem votar na nomeação de alguma Authoridade electiva Nacional, ou local. ARTIGO 94. - Pódem ser
eleitores e votar na eleição dos bros dos Conselhos de Provincia, todos os que podem Exceptuão-se: 1.0) Os que nâ. tiverem de renda liquida annual $200 \$ 000$ por bens de raiz, industria, commercio, ou em-
prego. 2.o) Os Libertos. $3 .^{\circ}$ ) prego. $2^{\circ}$ ) Os Libertos. $3^{\circ}$ )
$\mathrm{O}_{\mathrm{s}}$ criminosos pronunciados em querela, ou devassa.

ARTIGO 95.- Todos os que pódem ser Eleitores, são haDeputados. Exceptuam-se: $1^{\circ}$ ) Os que não tiverem $400 \$ 000$ de renda liquida, na forma dos Artigos 92 e 94. 2..$^{\circ}$ Os Estrangeiros naturalisados. $3 .^{\circ}$ ) gião do Estado.
GOTO DA COMMISSAO DECRETOS N. 510 DE 22 DE GOVERNO PROVISORIO DA "1.a" REPUBLICA

ARTIGO 85. - E' cidadão brasileiro todo aquele que, dades do art. 84 tenhe a edade de 21 annos completos e esteja alistado eleitor.

PARAGRAPHO UNICO - Não poderão ser alistados eleitores para os cargos fe

$\left.2^{\circ}\right)$ Os analphabetos; exercito e armads pret do ada e as de creada e sustentada pelos Es-

$\left.4 .^{\circ}\right)$ Os religiosos de ordens monasticas, companhias, des de qualquer denominação, uma vez que seus membros sediencia ou regra, ou estatuto que importe a perda ou o sa que importe a perda

\section{T14-A DE 23 DE}

ARTIGO 70. - São eleitoA fórma da lei.

$\left.\S 1 .^{\circ}\right)$ Não. podem alistare eleitores para as eleiçôes tados:

1. ) Os mendigos;

$\left.4 .^{\circ}\right)$ Os religiosos de orcongregacōes, ou communidades de qualguer denominação, regra, ou estatuto, que impore renuncia da liberdade in-

$\S 2 .^{\circ}$ ) A eleição para carlei do congresso. $\left.2 .^{\circ}\right)$ Os analphabetos;

ceptuados os alumnos das escolas militares de

( $3 .^{\circ}$ ) São inelegiveis os
REDACÇÃ FINAL DA ÇAOO DE $24 \cdot \mathrm{DE}$

FEVEREIRO DE 1891

ARTIGO 70. - São eleitoannos, que se alistarem fórma da lei.

(1.0) Não podem alistareleitores para alista federaes, ou para as dos $E$ tados:

2.0) Os analphabetos

$\left.3 .{ }^{\circ}\right)$ As praças de pret, ex colas militares de ensino su4. ${ }^{\circ}$ Os religiosos de orcongregações, ou communidades de qualquer denominação, sujeitas a voto de obediencia,
regra, ou estatuto que importe a renuncia da liberdade individual.

§ $\left.2 .^{\circ}\right)$ São inelegiveis os ci-

dadãos nåo alistaveis.
ANTE-PROJECTO DE CONS. TITUIÇAO ELABORADO PELA COMMISSAO NOMEADA PELO CHEFE DO GOERNO PROVISORIO DA

$$
\text { " } 2 \text { a" REPUBLICA }
$$

ARTTGO 98. - São cidadâos os brasileiros alistaveis penhem ou tenham desempenhado legalmente funç̧ão publica.

\$1.0) São eleitores os braores de 18 annos, alistados na fórma da lei.

$\left.\S 2 .^{\circ}\right)$ Não podem ser alistados: a) os analphabetos; b) as praças de pret, salvo os de ensino superior: c) que estiverem com a cidad onis suspensa, ou a tiverem perdido.
REDACÇAO FINAL DO PROJECTO DE CONSTITUICAAO

ARTIGO 115. - São eleitooutro nos, que se alistarem na forma da lei. \ Unico - Nāo se podem
alistar eleitores:

a) Os que não saibam ler rever;

b) As praças de pret, salvo os sargentos do Exercito e xiliares do Exercito, bem como os alumnos das escolas militares de ensino superior es asc) Os mendigos;

d) Os que estiverem, temprivados dos direitos politicos.
CONSTITUIÇAO DE JULHO DE 1934: O TEXTO

DEFINITIVO

ARTIGO 108. - São eleitores os brasileiros de um ou de nos, que se alistarem na fórma da lei.

8 Unico-Não se podem eleitores: escrever;

b) As pracas de pret, salvo os sargentos do Exercito da Armada e das forças aucomo os do Exercito, bem militares de ensino superior s aspirantes a official,

c) Os mendigos:

d) Os que estiverem, temprivados dos direitosivamente, 


\title{
CAPITULO II
}

\section{- ARTIGO 9 DO CODIGO CIVIL BRASILEIRO}

\author{
4. FONTES. \\ 5. EVOLUÇÃO. \\ 6. REDACÇÃO DO ART. 9 DO CODIGO CI- \\ VIL DE 1-1-1916. \\ 7. REDACÇÃO ACTUAL.
}

4. FONTES. - $O$ direito anterior era conforme, quanto ao principio do artigo 9 do nosso codigo civil (Resolução de 31 de outubro de 1831.) Discordante - era-o, porém, no tocante ao § Unico, actual § $1 .^{\circ}$ :

I - a) O filho, que já tivesse completado 18 annos (idade essa fixada e acceita pelos juristas mais autorizados de então) e que se achasse sob a autoridade paterna, - podia ser emancipado, fazendo o pae uma declaração, perante o juiz de orphãos, a quem competia homologar o acto e expedir a carta de emancipação (2);

b) deante da velha legislação reinicola, a mulher, aos 18 annos, e o varão, aos 20 , não sendo filhos familias, que tivessem obtido do juiz de orphãos, após as diligencias e informações regulamentares, a provisão de supplemento de idade, - aptos se tornavam para reger sua pessôa e bens (3) ; não podiam, comtudo, alienar, nem hypothecar os seus bens de raiz, sem autorização judicial.

(2) Ordenações do Reino, I, 88, § 6.', e Lei de 22 de setembro de 1828 , art. $2 .^{\circ}, \S 4 .^{\circ}$.

(3) Ordenações do Reino, 3, 42, pr. e $\S 1 .^{\circ}$; TeIXeIra dE Freitas, Consolidação das Leis Civis, art. 21; CARLOS de CARvalmo, Nova Consolidação, art. 97; Clovis BevilaQUA, Theoria Geral do Direito, pag 125; Doutor Waldemar Fepreira, $O$ Menor Commerciante, n. 9. 
Pela emancipação, - conquistavam os filhos familias a sua eapacidade civil, e aquella se processava em virtude de concessão expressa do pae, ou da mãe, por escriptura publica, ou por termo em autos judiciaes; ou graças ao casamento, dos menores filhos familias ou dos orphãos. Considerados maiores d'ahi para o futuro não se lhes permittia, comtudo, sem consentimento do juiz, e até que completassem 21 annos - alienar ou hypothecar bens de raiz, sob pena de nullidade dos contractos. Se gozavam da livre administração de sua pessôa e de seus bens, - licito não lhes era, porém, dispôr, livremente, de seus bens immoveis, ou oneral-os. Indispensavel, substancial, para a validade do acto, se tornava o consentimento judicial.

Quer o supplemento de idade, quer a emancipação, não lhes dava plena capacidade juridica. Extinguia o poder paterno, immitia-os na posse de seus bens. Deixavam de ser filhos familias, mas a sua capacidade tinha ainda limitações (4).

Entretanto o direito commercial veiu-lhes facultar o exercicio do commercio (Codigo do commercio, art. $1 .^{\circ}$, ns. 2 e 3 ), podendo obrigar e alienar os immoveis (Codigo do commercio, art. 26).

Com a promulgação do Codigo Civil essa antinomia entre o direito commercial e o civil - extinguiu-se.

II - Processava-se tambem a emancipação do menor pelo casamento (5); quanto ao orphão - algumas restriç̧ões havia (6).

III - IV e V - O primitivo projecto de Clovis Bevilaqua, revisto pelas commissões especiaes, considerava unicamente os dois primeiros casos de emancipação, dos enumerados pelo codigo civil. Uma emenda de FAusto Cardoso - approvada após amplos debates - deu entrada, em a nossa lei civil, aos outros casos. 0 direito anterior, não obstante em termos outros, já se referia a estes ultimos. Terminava o patrio poder, quer quando o filho não estivesse em companhia do pae, e estabelecesse economia separada; quer quando servisse officio publico, ainda que estivesse em companhia do pae. O mesmo succedia em relação aos bachareis for-

(4) Doutor Waldemar Ferreira: Obr. e lug. cits.

(5) Ordenações do Reino, $1,88, \S 6 .^{\circ}$.

(6) Id., 1, 88, $\S \S 19,27$ e 28 . 
mados, por simples effeito de seu grau; e aos clerigos de ordens sacras, por effeito de sua ordenação (7).

5. EVOLUÇÃO. Pelas leis republicanas - aperfeiçoou-se, e muito, o art. 9 do codigo civil, maximé ao declarar que se não consideravam filhos familias os maiores de 21 annos, ainda que na companhia dos paes.

A carta republicana lhes concedera o direito do voto e a lei do casamento civil lhes consentira casar, sem necessidade da autorização paterna.

Pelas linhas acima se verifica como é tardo o direito civil no seu evolucionar: não fôra elle profundamente tradicional! "Lento no evolver-se. Particularista no concernente ás relações de família e de sucessão hereditária. Adstrito á organização da propriedade territorial. Eminentemente conservador. Envolvendo, em sua integridade, a personalidade humana, no que cada um possue de mais íntimo, a sua pessoa e a sua família, a sua prole e os seus bens, não podia deixar de ser fundamentalmente tradicionalista.

"Um exemplo nunca é demais. Ainda sob o regime colonial, logo depois da abertura dos portos brasileiros á navegação e ao comércio estrangeiros, sugeriu José DA SiLva LissôA a elaboração de um código de comércio, pela consolidação das regras em voga na praça do Rio de Janeiro. Deram-se os primeiros passos nesse sentido. Mais seguros e profícuos se tornaram com a independência do Brasil. Voltou o assunto ao tapête da discussão. Constituído o poder legislativo, cumpriu-se a promessa contida na lei primária. Elaborou-se o projecto. Discutiu-se. Converteu-se em lei.

"Promulgado o código de comércio, continuou o direito civil subordinado ás velhas Ordenações do Reino, desde 1867 substituídas, em Portugal, pela sua codificação civil: vigoraram elas, com as modificąões introduzidas por leis esparsas, até 1916.

(7) Augusto ThxmRA DE Frmtas: Consolidação das Leis Civis, V 1, pag. 170 . 
"Eis a fôrça de inércia do direito civil." (8)

0 argumento gizado neste Capitulo não deve ser esquecido. ao se procurar resolver a presente these.

\section{REDACÇÃO DO ART. 9 DO CODIGO CIVIL DE 1-1-1916.} - Pela sua redacção se verifica que o codigo civil brasileiro de 1-1-1916 não indicou a idade com que se poderão emancipar os menores que se dedicarem á funç̧ão publica, collarem grau scientifico, ou se estabelecerem, civil ou commercialmente, com economia propria, como houve por bem fazer para o caso de outorga paterna ou de casamento.

O sentir de Spencer Vampré a respeito do ultimo caso (o de emancipação por estabelecimento civil ou commercial, com economia propria) é de que se torna necessario tomar em consideração a idade : em a sua opinião o menor deverá ter 18 annos cumpridos para que possa emancipar-se. (9)

Interpretação essa, comtudo, não decorre do texto legal. Se fôra intenção do legislador a de marcar a idade de 18 annos para todos os casos de emancipação - são palavras do Professor Doutor WaLdemar Ferreira - isso mesmo teria elle declarado.

"Não o fez, sinão no caso della se dar por concessão dos paes. E a regra, si enunciada tivesse sido, exigiria uma excepção: a de que pelo casamento, á mulher é permittido emancipar-se aos 16 annos. Ademais, nada se oppõe a que, antes dos 18 annos, sejam menores nomeados para cargos publicos, recebam grau scientifico, ou se estabeleçam com economia propria."

"Razão é essa porque Esprnola assegura ser fóra de duvida que o limite da idade minima de 18 annos não vigora em relação aos tres ultimos casos do art. 9 do Cod. civil, e só tem applicação. nos dois primeiros (10). E isso mesmo, dever-se-ia accrescentar,

(8) Professor Doutor Waldemar Ferreira: Tratado de Direito. Mercantil Brasileiro, Vol. 1. ${ }^{\circ}$, Parte Geral, 1934, pag. 68.

(9) Profesor Doutor Spencer Vampré: Codigo Civil Commentado, Vol. $1 .^{\circ}$, pag. 15.

(10) Eduardo Espinola: Breves Annotações ao Codigo Civil Brasileiro, Vol. $1 .^{\circ}$, pag. $72, n .^{\circ} 47$. 
no segundo delles, no de casamento, apenas quanto á idade do varão, e não quanto á da mulher" (11)

Como nos ensina o insigne cathedratico da nossa Faculdade de Direito, Professor Doutor Honorio Fernandes Monteiro: "Ém face da lei civil vigente, tanto a menor de 16 annos, quanto a de 18, pelo casamento, adquire a inteira capacidade civil, a livre administração de sua pessoa e de seus bens, com as restriç̧ões impostas a toda mulher casada, como consequencia do proprio casamento." (12)

Estatue o Codigo Civil de 1-1-1916 em o seu artigo 9 que commentámos acima:

ART. 9-"Aos vinte e um annos completos, acaba a menoridade, ficando habilitado o individuo para todos os actos da vida civil.

§ Unico - Cessará, para os menores, a incapacidade :

I. Por concessão do pae, ou, se fôr morto, da mãe, e por sentença do juiz, ouvido o tutor, se o menor tiver dezoito annos cumpridos.

II. Pelo casamento.

III. Pelo exercicio de emprego publico effectivo.

IV Pela collação de grau scientifico, em curso de ensino superior.

V Pelo estabelecimento civil ou commercial, com economia propria.

7. REDACÇÃO ACTUAL. - Com a introducção do novo paragrapho, de que trata o Decreto N. 20.330 de 27 de agosto de 1931, a redacção do Art. 9 do nosso Codigo Civil passou a ser a seguinte :

(11) Professor Doutor Waldemar FERREIRA: $O$ menor commerciante, n. ${ }^{\circ} 42$.

(12) Professor Doutor HONORIO FERNANDES MONTEIRO: Da mulher casada commerciante, 1929, pag. 66 . 
ART. 9 - Aos vinte e um annos completos, acaba a menoridade, ficando habilitado o individuo para todos os actos da vida civil.

$\$ 10^{\circ}$ - Cessará, para os menores, a incapacidade:

I. Por concessão do pae, ou, se fôr morto, da mãe, e por sentença do juiz, ouvido o tutor, se o menor tiver dezoito annos cumpridos.

II. Pelo casamento.

III. Pelo exercicio de emprego publico effectivo.

IV Pela collação de grau scientifico, em curso de ensino superior.

$\nabla$ Pelo estabelecimento civil ou commercial, com economia propria.

$\S 20^{\circ}$ - Para effeito do alistamento e do sorteio militar cessará a incapacidade do menor que houver completado 18 annos de idade. 
PROJECTO DE EMENDAS AO PROJECTO DO CODIGO COMMERCIAL, PARA O FIM DE O TRANSFORMAR EM CODIGO BRASILEIRO DE DIREITO PRIVADO (INGLEZ DE SOUZA)

“ARTIgo 9. - Aos 21 annos completos termina a menoridade e a pessôa fica habilitada para todos os actos da vida civil.

ARTIGO 10. - A incapacidade resultante da menoridade cessa:

I - por concessão do pae, ou da mãe, se o mellor não tiver pae, feita por escriptura publica, tendo o menor a idade de 18 annos completos;

II - pelo casamento, celebrado com a autorização dos paes ou do Juiz, como se determina no Livro VI deste Codigo;

III - pelo exercicio de emprego publico effectivo, tendo - menor a idade de 18 annos completos;

IV - pelo exercicio do commercio com autorização nos termos do artigo..."
REDACCAOO DO PROJECTO

PRIMITIVO, DO REVISTO E

DO DA CAMARA DOS DEPUTADOS

Tanto o projecto primitivo como o revisto (art. 9) não falam, na PARTE GERAL sinão de maioridade e decla ração de maioridade dos filhos-familias e orphams que tenham ultrapassado os 18 annos.

Na PARTE ESPECIAL consagrada ao DIREITO DE FAMILIA, estatuiram, em ad ditamento, que o casamento contrahido na idade legal tinha por effeito conferir a emancipação plena aos conjuges (1).

O projecto da Camara dos Deputados mudando a denominação de DECLARAC̄̃̃ DE MAIORIDADE para EMANCIPAÇÃO, transportou para a PARTE GERAL to $(2)$.

(1) PROJECTO PRIMITIVO:

ART. 271. - "Os menores ficam, de Direito, emancipados pelo casamento realizado na idade legal".

\section{PROJECTO REVISTO:}

ART. 296. - "Os menores ficam, de Direito, emancipados pelo casamento realizado na idade legal".

(2) Clovis Bevilaqua, Em defeza do Projecto de Codigo Civil Brazileiro, Livraria Alves, 1906, pags. $349-351$.
REDACÇAO DO PROJECTO DA CAMARA DOS DEPUTADOS. PARECER DO SENADOR RUY BARBOSA (TEXTO DO PROJECTO, NOTAS E EMENDAS)

ARTIGO 9. - Aos vinte e um annos completos termina a menoridade e a pessoa fica habilitada para o exercicio de todos os actos da vida civil.

$\$$ UNICO. - Tambem cessará a incapacidade:

I -- Por concessão do pae, ou da mãe, se fôr aquelle fallecido e por sentença do juiz, ouvindo o tutor, "se o menor estiver sob tutela", para os menores que tiverem completado dezoito annos.

"Se o menor estiver sob tutela". Desnecessaria esta expletiva. Claro está que, se ha tu'or, a quem se oiça,

é porque o menor se acha em tutela."

II - Pelo casamento.

III - Pelo exercicio de emprego publico effectivo.

IV - Felo recebimento de sráo scientifico dos cursos superiores.

V - Pelo "estabelecimento" civil ou commercial, com economia propria.

"P elo estabelecimento". Expressão não erronea, mas de escolha pouco feliz. $\mathrm{Pa}$ rece indicar antes a casa ou logar onde se uma pessoa estabelece que o acto ou facto de estabelecer". (1)

(1) Senador RUY BARBosA parecer sobre a Redaccão do Projecto da Camara dos Deputados, "in" Projecto de Codigo Civil Brazileiro, Trabalho de Commissâo Especial do Senado vol. I, Rio de Janeiro, Imprensa Nacional, 1902, pag. 36.
REDACCÃO DO ART, 9 DO CODIGO CIVIL BRASILEIRO DE 1-1-1916.

ARTIGo 9. - Aos vinte e um annos completos, acaba a menoridade, ficando habilitado o individuo para todos os actos da vida civil.

PARAGRAPHO UNICO. -Cessará, para os menores, a incapacidade:

I - Por concessão do pae, ou, se fôr morto, da mãe, e por sentença do juiz, ouvido o tutor, se o menar tiver dezoito annos cumpridos.

II - Pelo casamento.

III - Pelo exercicio de emprego publico effectivo.

IV - Pela collação de grau scientifico, em curso de ensino superior.

V - Pelo estabelecimento civil ou commercial, com economia propria.
REDACÇÃo DO ART. 9 DO CODIGO CIVIL APGS A EXPEDIÇÃO DO DECRETO N. 20.330 DE 27-8-1931

ART. $90^{\circ}$ - Aos vinte e um annos completos, acaba a menoridade, ficando habilitado o individuo para todos os actos da vida civil.

$\S 1 .^{\circ}$ Cessará, para os menores, a incapacidade:

I. Por concessão do pae, ou, se fôr morto. da mãe, e por sentença do juiz, ouvido o tutor, se o menor tiver dezoito annos cumpridos.

II Pelo casamento.

III Pelo exercicio de emprego publico effectivo.

IV - Pela collação de grau scientifico, em curso de ensino superior.

V Pelo estabelecimento civii ou commercial, com economia propria.

$\S 2 .^{\circ}$ Para effeito do alistamento e do sorteio militar cessará a incapacidade do menor que houver completado 18 annos de idade. 


\section{NA ASSEMBLÉA NACIONAL CONSTITUINTE D E 34}

\section{FECHANDO ESTE L I V R O I}

8. FECHANDO ESTE LIVRO I. - Os discursos proferidos perante jurisperitos, jurisconsultos e demais homens do direito na Assembléa Nacional Constituinte de 33-34 - já de antemão nos podem permittir um juizo (Vide ANNEXO n. 1).

Dos debates travados naquella Assembléa verifica-se:

$10^{\circ}$ - que os oradores $\mathrm{SO}^{\prime}$ debateram a questão da EXTENSÃO DO DIREITO DE VOTO AOS MENORES DE 21 ANNOS E MAIORES DE 18;

$2 .^{\circ}$ - que Só houve allusão aos cidadãos COMO MEMBROS DO ESTADO.

$3 .^{\circ}$ - que em tão augusto Congresso ninguem gizou ou mesmo esboçou o problema das consequencias que sobreviriam se se estivesse tratando dos cidadãos considerados no seu caracter, condição e relações particulares.

Por ser essa fonte, em a nossa opinião, muito importante: sobre a sua origem historica discorremos em o Cap. I do Livro I (Vide, ainda, Da acta da $148 .^{a}$ sessão ordinaria da Assembléa $\mathrm{Na}$ cional Constituinte, que na presente obra figura em o ANNEXo n. 1).

Note-se: no Congresso Constituinte de 34 havia não pequeno numero de deputados (94) e, entre elles, alguns Mestres de Direito, contrarios a essa extensão do direito de voto; para combater esta 
ultima, e isto se a emenda do sr. Aloysio Filho (12) aso désse a uma tão lata interpretação - qual a de, pela sua approvação, abrogar o artigo 9 do nosso codigo civil - esquecidos não seriam, pelos alludidos homens do direito, os argumentos expendidos em o final do n. 5 do Cap. II, do Livro I, deste modesto trabalho, porisso que as instituições politicas de um paiz podem mudar-se de chofre, mas a sociedade civil alterada nunca poderá ser de uma só vez: secular é a sua transformação.

Mas, não nos antecipemos.

A presente dissertação, toda ella, foi feita visando elucidar o assumpto.

Escriptos de publicistas sobre a materia são muito escassos:

"Et nobis, que hoc opus suscepimus, non facilem laborem, imo vero negotium plenum vigilarum et sudoris assumpsimus" (Mach., lib. II, cap. II, v. 27).

Não obstante - se vigilias nos absorveu esta despretenciosa dissertação para vencer as difficuldades que se nos entolhavam e se muito nos fizemos guiar pelos Mestres que atraz mencionámos, - terá o benevolo leitor ensejo de observar que, acompanhando-os e não raro textualmente mesmo: de lado não puzemos, porém, o nosso criterio pessoal e o resultado de nossos proprios estudos.

No corpo desta monographia juntámos muitos documentos eis-que só elles pódem provar os factos; e cremos que isso é proprio de uma dissertação, pois taes documentos, como diz um historiador bem celebre (13) são como os andaimes nos edificios, e os esteios, e formas nas abóbadas, que se tiram feita a obra, ficando bem claro, que sobre ellas é que se fundou.

(12) Essa emenda foi approvada por 96 votos: venceu apenas pela differença de 2 votos! (VIDE ANNEXO n. 1)

(13) Abbade Fleury: Discurso primeiro sobre a Historia Ecclesiastica. 


\section{LIVRO II}

AS DUAS INTERPRETAÇÕES 


\section{CAPITULO I}

\section{O ARTIGO 9 D O C O D IGO C I V IL ESTARIA ABROGADO}

9. A CONSTITUIÇÃO ACTUAL E A MATERIA DE DIREITO CIVIL.

10. O SENTIR DO PROFESSOR DOUTOR CLOVIS BEVILAQUA.

11. O SENTIR DO PROFESSOR DOUTOR JORGE AMERICANO.

9. A CONSTITUIÇÃO ACTUAL E A MATERIA DE DIREITO CIVIL. - Em conferencia que realizou na cidade de Fortaleza, o illustre escriptor Doutor Clovis Bevilaqua fez vêr que a Constituição actual contem materia de direito civil. Dessa materia, alguma coisa, em o seu modo de entender, é louvavel e outra censuravel.

10. O SENTIR DO PROFESSOR DOUTOR CLOVIS BEVILAQUA. - Commentando a nossa nova Carta Magna disse o grande civilista:

"Começa a maioridade politica aos 18 annos, para um e outro sexo (Constituição, artigo 108, pr.).

"A capacidade civil, segundo o Codigo, artigo 9, exige idade mais adiantada. Somente aos 21 annos se adquire. Estará abrogado o preceito do Codigo Civil?

"Hesitei em decidir-me, diante da gravidade da materia diz-nos ainda o erudito autor -; mas, por fim, tive de reconhecer que, se aos dezoitos annos o individuo está apto para intervir na 
direcção dos interesses da collectividade nacional, como eleitor e como eleito, seria illogico desconhecer-lhe capacidade para gerir os seus proprios negocios. Como, porém, somente os que sabem lêr e escrever podem alistar-se como eleitores, força é reconhecer que somente esses, depois de alistados, gozarão tambem da plenitude dos direitos civis, aos 18 annos completos.

"Aliás, para o effeito do alistamento e do sorteio militar, já cessava a incapacidade do menor que tenha completado 18 annos de idade (dec. n. 20.330, de 27 de agosto de 1931)." (14)

No presente LIVRO II por objectivo temos unicamente relatar, a respeito do assumpto proposto nesta these, as interpretações dadas pelos autores que formos citando. Em occasião e lugar opportunos a ellas volveremos.

11. O SENTIR DO PROFESSOR DOUTOR JORGE AMERICANO. - Do insigne Professor Cathedratico de Direito Civil da nossa Faculdade de Direito é o parecer: "Penso que o dispositivo constitucional, que estendeu o direito de voto aos individuos que completaram 18 annos, creou um novo caso de emancipação.

"Não é concebivel que o individuo que exerce o voto esteja debaixo de patrio poder ou de tutela.

"O principio da liberdade do voto collide com a possibilidade de continuar o eleitor sob o patrio poder ou sob tutela. A subordinação ao pae ou ao tutor, o temor reverencial consistente no receio de contrariar o pae ou o tutor constitue coacção moral incompativel com a liberdade de consciencia indispensavel ao exercicio do voto.

"Si a lei annulla todo voto coacto, e bem assim nega apuração á urna em que se prove terem sido depositados votos comprovadamente coactos; si a lei veda expressamente toda especie de propaganda eleitoral nas ultimas 24 horas anteriores á eleição, si prohibe que se faça distribuição de cedulas no recinto, e até 100 metros de distancia, não seria possivel acceitar como legitimo o voto do individuo "alieni juris".

(14) Doutor Clovis Bevilaqua: Conferencia realizada em Fortaleza, "in" "O Estado de São Paulo", pag. 5, de 21 de março de 1935. 
“Aliás no processo de alistamento eleitoral, não será considerado eleitor o individuo "alieni juris".

"Ora, desde que mantido esse principio, é licito ao menor alistar-se é porque os passos dados pelo menor para alistar-se são passos para a sua emancipação, tal qual se verifica com a obtenção do diploma em curso superior.

"O titulo de eleitor emancipa, tal qual o diploma de escola superior.

"Não se diga que é possivel ser politicamente capaz, conservada a incapacidade civil, em face do principio de que a lei politica tem esphera de actuação diversa.

"A lei politica de ordem constitucional é de hierarchia superior á lei civil, de modo que, dispondo em contrario ao principio da lei civil, revoga-o. Não pode co-existir esta com aquella, tal qual succede com a lei commercial que, quando dispõe diversamente da lei civil, só alcança a esphera de actuação do direito civil.

"Onde dispõe a lei constitucional de certo modo, a regra por ella fixada sobrepõe-se a todas as regras contrarias, das leis hierarchicamente inferiores. 0 direito civil cede ao direito constitucional." (14-a).

(14-a) Entrevista obtida pelo autor desta dissertação no dia 24 de maio de 1935, sexta-feira, ás 12 horas, na Sala dos Srs. Lentes. 


\section{A INTERPRETAÇÃO CONTRÁRIA}

12. O SENTIR DO PROFESSOR DOUTOR FRANCISCO MORATO.

13. O SENTIR DO PROFESSOR DOUTOR SAMPAIO DORIA.

14. O SENTIR DO PROFESSOR DOUTOR WALDEMAR FERREIRA.

15. O SENTIR DO PROFESSOR DOUTOR AZEVEDO MARQUES.

\section{O SENTIR DO PROFESSOR DOUTOR FRANCISCO} MORATO. - Eis o que nos disse (15) o Professor e actual Director da Faculdade de Direito da Universidade de S. Paulo, Doutor Francisco Morato, o maior e melhor biographo do saudoso jurisconsulto Doutor JoÃo Mendes Junior : “O artigo 108 da Constituição de julho de 1934 - refere-se unicamente á capacidade politica. A maioridade civil é, ainda, a que o Codigo Civil prescreve : começa quando o individuo completa 21 annos de idade - a não ser a sua acquisição, antes da idade legal, por qualquer dos modos indicados no artigo 9 do nosso codigo civil.

"Cumpre notar que a esphera da capacidade civil é muito mais ampla que a da capacidade politica. Reflecte-se, aquella, de u'a maneira mui vasta na vida biologica e social do individuo; ao passo

(15) Nas conversações que tivemos com os eminentes e illustres Mestres: uma vez ou outra tomámos algumas notas no instante mesmo; vezes outras - registrámos, logo depois de ouvil-as, as sábias lições dos insignes professores de nossa Casa de Direito. Não reproduzimos neste trabalho, pois, textualmente as palavras que os preclaros entrevistados proferiram; não obstante cremos ter conservado o espirito nellas contido. 
que esta ultima só existe para o exercicio dos direitos politicos: não é tão vasta como a outra capacidade e não exige certos requisitos que só a lei civil poderia reclamar pela delicadeza do assumpto." (16)

13. O SENTIR DO PROFESSOR DOUTOR SAMPAIO DORIA. - "A capacidade civica - externou-nos o eminente Cathedratico de Direito Constitucional - é distincta da capacidade civil: o que a Constituição de 34 determinou foi - attribuir aos menores de 21 annos, e maiores de 18, a capacidade de ser eleitor, e, absolutamente, não cuidou da capacidade civil. Logo: não revogou - manteve as condições estatuidas em a nossa lei civil a respeito da capacidade civil." (17)

\section{O SENTIR DO PROFESSOR DOUTOR WALDEMAR} FERREIRA. - De pensar identico aos acima enunciados é o Professor Waldemar Ferreira: "O artigo 108 da Constituição de julho de 34 , contrariamente ao que affirmou Clovis Bevilaqua, não abrogou o artigo 9 do nosso Codigo Civil." (18)

\section{O SENTIR DO PROFESSOR DOUTOR AZEVEDO} MARQUES. - O illustre Presidente da Ordem dos Advogados, na Seção de São Paulo, em um bem fundamentado parecer que foi approvado pelo seu Conselho - veiu contribuir enormemente para esclarecer a questão (Vide o parecer, por extenso, em o ANNEXO N. 2).

Eis alguns de seus magnificos trechos que, embóra se refiram á mulher casada, têm inteira applicação nesta dissertação - eis-que: trata-se, tambem, de um caso de incapacidade civil relativa (Art. 6. ${ }^{\circ}$ do Codigo Civil).

(16) Entrevista obtida pelo autor deste trabalho no dia 18 de maio de 1935, sabbado, ás 15 horas, na Sala da Directoria da Faculdade de Direito.

(17) Entrevista obtida pelo autor deste no dia 14 de maio de 1935, terça-feira, ás 13 horas, proximo á Sala dos Srs. Lentes.

(18) O illustre deputado federal por S. Paulo fidalgamente attendeu ao nosso objectivo, em seu escriptorio, em 8-V-1935, ás 15,30 horas. Prometteu-nos dar, futuramente, por escripto, seu parecer fundamentado. 
"A Constituição - escreveu o Doutor Azevedo Marques creou o dever de alistamento eleitoral e voto obrigatorio para as mulheres que exercerem função publica remunerada (art. 109). Esse dever "politico", assim como o direito de ser eleita, ou a elegibilidade da mulher, não acarreta, por si só, a capacidade "civill", derrogando o art. 242 do Codigo Civil".

E mais adeante: "Deu á mulher o direito de exercer cargos publicos, eletivos ou não, mas com a ressalva (art. 168): "observadas as condições que a lei estatuir". Enfim, estão de pé todas as condições que as leis estabelecerem, quanto á capacidade civil, que não se confunde com a capacidade "politica". (19).

(19) Professor Doutor Azevedo MARques: Parecer apresentado no Conselho da Ordem dos Advogados, Seç̧ão de S. Paulo e publicado "in" Revista de Critica Judiciaria, Ns. 2-3 - Fevereiro e Março de 1935 Anno XII - Vol. XXI, pags. 169-173. 


\section{LIVRO III}

CAPACIDADE CIVIL E CAPACIDADE CIVICA OU POLITICA 


\title{
CAPITULO I
}

\section{O QUE SE ENTENDE POR CAPACIDADE CIVIL}

\author{
16. PRELIMINARMEITE... \\ 17. PESSOA - PERSONALIDADE - CA- \\ PACIDADE \\ 18. CAPACIDADE CIVIL \\ 19. DIREITOS CIVIS
}

16. PRELIMINARMENTE. - A resolução desta these depende essencialmente de uma distincção a se fazer preliminarmente entre capacidade civil e capacidade civica ou politica.

Estabelecida a linha divisoria entre uma e outra - desapparecerá, crêmos nós, o nevoeiro, através do qual scintilla a estrella favorita do valle.

\section{PESSÔA - PERSONALIDADE - CAPACIDADE.}

- Na linguagem juridica a palavra "pessôa" possue um sentido preciso: assim se denomina todo o sêr, real ou ficticio, considerado como sujeito de direitos, como tendo ou podendo ter direitos (20).

"Todo sêr real ou ficticio" - eis-que em direito ha a "pessôa naturul" e a "pessôa juridica" Neste trabalho só nos interessa aquella.

"A pessôa - dizia aquelle que era "um homem insigne na sciencia, insigne no caracter, insigne na modestia" - é uma subs-

(20) Cн. Beudant, Cours de Droit Civil Français, Tome Premier, L'Etat et la Capacité des personnes, Paris, 1896. 
tancia individual de natureza racional e social. E' uma substancia individual, que vive na sociedade, em cujo seio exerce direitos de homem e de cidadão" (21).

"Pessôa é o ser a que se attribuem direitos e obrigações" (22). "Personalidade é a aptidão, reconhecida pela ordem juridica a alguem, para exercer direitos e contrahir obrigações. Na ordem politica, toma, ordinariamente, a feição de "cidadania", que é a aptidão para exercer direitos politicos, e é "soberania" quando attribuida ao Estado." (23).

Todo homem é, pois, uma pessôa. A personalidade, a aptidão para ser sujeito de direitos, começa para o homem desde o seu nascimento ou, mais exactamente, desde sua concepção. O embryão féto, depois - não tem uma vita autonoma: eis-que é do organismo materno que retira, por intermedio da placenta, os materiaes nutritivos que lhe são necessarios para a sua vida intra-uterina. Nesse estadio de sua evolução (estadio embryonario ou, após, estadio fetal) - não se póde dizer propriamente que haja uma personalidade distincta. Não obstante: para os effeitos legaes reputa-se como se nascido fôra, e, por consequencia: como sendo uma "pessôa" (pelo menos emquanto o seu interesse o exija). São os direitos do nascituro. E' uma antiga regra; já dizia o direito romano: "Infans conceptus pro nato habetur quoties de commodis ejus agitur." (24).

Sufficiente não é, porém, ter nascido, ter personalidade, para que o homem se considere apto para exercer, por si, os actos da vida civil, exercer direitos, ou contrahir obrigações.

Para isso necessita elle da "capacidade", que Augusto Teixeira de Freitas definiu: "o modo de ser geral das pessôas", e Clovis Bevilaqua: "a extensão dada aos poderes de acção contı. dos na personalidade"

(21) Professor Doutor João Mendes de Almeida JoR.: O Processo Criminal Brazileiro, 3. ${ }^{\mathrm{a}}$ Ed., 1920, Vol. I, pag. 5.

(22) Doutor Clovis Bevilaqua, Theoria Geral do Direito Civil, 2. Ed. 1929, pag. 80.

(23) Id. Ob. e Loc. Cits.

(24) Digesto, De statu hominum, Fragm. 26, I, 5. 
Distinguir, portanto, da "personalidade" a "capacidade", cumpre.

"A capacidade juridica - são palavras do grande civilista italiano G. P. ChIron - é a possibilidade juridica de agir, de modo que, sendo o direito o poder de querer juridicamente, são capazes as pessôas que, por sua natureza, têm tal possibilidade, a qual confirmada pela lei, é poder : e as outras ás quaes a lei a concede: estas têm uma capacidade limitada aos casos nos quaes ella é expressamente declarada pela lei.

"Esta capacidade de ter direitos exprime, dest'arte, a natureza juridica de quem é sujeito de direito: quem o fôr é porque tom aquella capacidade. Comtudo - quem é capaz de ter direitos (possibilidade de poder), bem póde ser incapaz de agir para os exercitar." (25).

A capacidiade, como se deprehende do exposto, - é a regra; e, em face da nossa lei civil: aos 21 annos encontra-se o individuo apto para praticar todos os actos da vida civil. Cessa, nesse caso, a menoridade. Cessam, então, tambem, as restriç̧ões á capacidade. A incapacidade - é a excep̧̧ão (26).

Em todo o systema do direito toma, portanto, o nome de "capacidade" - a faculdade de validamente consentir uma propria obrigação ou liberação. E' conseguintemente, “incapacidade" - a privação da mesma faculdade de validamente consentir: nas hypotheses contrárias. (27).

(25) G. P. ChIronr, Instituzioni di Diritto Civile Italiano, 2. ${ }^{\text {a Ed, }}$ 1912, Vol. $10^{\circ}$, pag. $74, \S 29$.

(26) Vide: Prof. Dr. WALDEMAR FERREIRA: $O$ menor commerciante, ns. 1-3.

(27) "In tutto il sistema del diritto prende nome di "capacità" la facoltà di consentire validamente una propria obbligazione o liberazione. È poi detta “incapacità" la privazione della facoltà medesima di validamente consentire; nelle ipotesi contrarie. E poichè il consenso riferito alle obbligazioni ed alle liberazioni, ossia giuridicamente riguardato, è fatto od atto delle personne; la capacità suddetta e la incapacità contraria talmente appartengono al diritto delle personne, ch'esse tutte si potrebbero distinguere generalmente in due categorie; l'una delle "personne capaci", l'altra delle "personne incapaci"; sempre intendendosi delle facoltà di assumere mediante valido consenso, e ricevere obbligazioni o libe- 
18. CAPACIDADE CIVIL (28). - Capacidade civil é " $a$ aptidão de alguem para exercer por si os actos da vida civil" (29). Nosso grande Teixeira de Freitas (30) e o escriptor hespanhol Sanches Roman (31) designam-na: "capacidade de facto" - differente da "capacidade de direito", a qual consistiria na

razioni. E però i nostri giureconsulti dal "capere", che vale prendere, apprendere, acquistare, e simili, chiamano "capax": con chiara etimologia, la persona capace, dicendo anche "capacitas" quella che noi chiamamo capacità delle persone nella significazione anzidetta" GIRolamo SCALAMANDRì, in Il Digesto Italiano - Enciclopedia Metodica ed Alfabetica di Legislazione, Dottrina e Giurisprudenza, Vol. Sesto - Parte Prima, Torino, 1888, pag. 686. Indicação bibliographica da Faculdade de Direito da Universidade de S. Paulo: K3 - $21-1$.

(28) "Capacidade" (F. J. CALDAS AUlETE: Diccionario Contemporaneo da Lingua Portugueza), s. f. .. (For.) Faculdade legal: 0 menor não tem "capacidade" para coniractar sem autoridade do curador (Paiva) .. F. lat. "capacitas".

"Capacidade" (ANTONIO DE MORAES SILva: Diccionario da Lingua Portugueza), s. f. $\quad$ E fig. do entendimento, por habilidade para adquirir dotes do entendimento, e da vontade; ou por esses dotes adquiridos, faculdade, poder físico, ou moral, "tão longe, e tão fóra de sua capacidade, e jurisdição. Paiva, "Serm. I. fr. 33. "o menor não tem capacidade para contractar".

"Capacidade" (JAYME SEGUIER: Diccionário Prático Illustrado), s. f. (1. "capacitas") Intelligencia, sciencia, aptidão: "pessoa de alta capacidade" .. - Direito legal: "a mulher casada não tem capacidade para contratar sem autorização do marido" etc.

"Capacidade" (CANDido FigueIRedo: Pequeno Diccionario da Lingua Portuguesa), f. .. Qualidade, que uma pessôa "ou" coisa tem, de satisfazer a certo fim. Aptidão ... Possibilidade legal.

"Civil" (F. J. CAldas Aulete: (Dicc. cit.): adj. que diz respeito ao cidadão considerado no seu caracter, condição e relações particulares: Vida civil. Sociedade civil. Comportamento civil. Direitos e obrigações civis. DIZ-SE POR OPPOSIÇÃO A POLITICO .. F. lat. "civilis".

"Civil. (JAYMe SÉGUIER: Dicc. cit.), adj. (lat. civilis). Que diz respeito ás relações dos cidadãos ENTRE SI: direitos civis, etc.

(29) Doutor Clovis Bevilaqua, Theoria Geral do Direito Civil, 2. ${ }^{2}$ Ed., 1929, pag. 82 .

(30) Augusto Teixeira de Freitas, Esboço, arts. 21 e 22.

(31) Sanches Roman, Derecho Civil Español, II, pags 116-118. 
aptidão para adquirir direitos e exercel-os por si ou por outrem. Endemann (32), Dernburg (33) e Roth (34) falam de uma capacidade de direito (Rechtsfähigkeit) como diversa da faculdade de agir (Geschäftsfähigkeit). Huc (35), LaURENT (36) e Planiol (37) distinguem o "gozo" do "exercicio" dos direitos. "Gozo de um direito" é a aptidão legal de uma pessôa para se utilizar das vantagens reconhecidas ou sanccionadas pela lei. "Exercicio de um direito" é a realização effectiva do gozo. Gozar de um direito é ser titular delle; exercel-o é extrahir delle as vantagens que possa fornecer. Para Carlo Scotti (38): "Goza-se de um direito, quando se possue "a faculdade" de usal-o, "ainda que seja em potencia, e não em acto"

De sorte que a idéa de gozo corresponde á de capacidade de direito; a de exercicio não corresponde á de capacidade, porém a presuppõe. "Esta antithese vae sendo posta de lado pela doutrina, que prefere estabelecer a gradação da actividade juridica, indo da capacidade para o exercicio. A "capacidade" é a extensão concedida aos poderes de acção, em que consiste a personalidade; o "exercicio" é um momento ulterior, em que a personalidade realiza, segundo a medida da capacidade, os poderes que a ordem juridica lhe assegura. E como na "capacidade" ha medida para a acquisição de direitos, estabelecimento de obrigações, modificação e extincção de uns e outras, no "exercicio" se devem reflectir esses diversos modos da actividade juridica. E' certo que o exercicio do direito é contrario á idéa de obrigação ou encargo, mas

(32) EndemanN, Einführung, I, §§ 21 e 24.

(33) Dernburg, Pandette, § 49.

(34) Rотн, System des deutschen Privatrechts, § 60.

(35) Huc, Commentaire, I, n. 219.

(36) Laurent, Principes, I, n..$^{\circ} 319$.

(37) Planiol, Traité, I, n. $0^{\circ} 416$.

(38) CARLo SCOTTI,: "Si gode di un diritto, quando si possede "la facoltà" di usarne, "sia pure in potenza, e non in atto". Manuale di Diritto Civile Italiano, Vol. I, pag. 3, n. $^{\circ} \mathbf{5}$. 
quem contráe uma obrigação exerce uma faculdade e torna possivel o exercicio de direitos de outrem." (39)

Differentes da capacidade civil, de que óra tratamos, - outras especies de capacidades juridicas existem. Comquanto diversas, tambem estas ultimas apresentam uma certa connexão com aquella, tanto no direito privado, como no direito publico.

Em relação ao direito privado: quem é plenamente capaz pelas leis civis, - capaz tambem o é para o direito commercial. A capacidade commercial é fundamentalmente a mesma capacidade juridica contractual, estabelecida no direito civil. As pessoas, de ambos os sexos, capazes, na conformidade da lei civil, de adquirir e obrigar-se por contracto, estão habilitadas a ser commerciantes. Os que se enquadrarem nos artigos 5 e 6 da nossa lei civil - não têm capacidade para exercitar o commercio: se se encontrarem assignalados no art. 5 - são elles absolutamente incapazes, e, portanto, não podem contractar (integralmente nullos seriam os actos e contractos em que tomassem parte); se se encontrarem, porem, incluidos no art. 6 - poderão fazer cessar a incapacidade, adquirindo elles a faculdade de administrar plenamente, livremente, suas pessôas e bens, como se maiores fossem - se preenchidas estiverem as condições estatuidas em 0 ₹ $11^{\circ}$ do artigo 9 do Codigo Civil.

Differente, porém, será o caso se se tratar de capacidade eleitoral, politica ou administrativa: Nesta hypothese - e, semelhantemente, para com as incapacidades contrárias - a capacidade aventada não tem affinidade com 0 direito civil, a não ser que, com este ultimo, uma correlação seja estabelecida por leis especiaes $(40)$.

(39) Clovis Bevilaqua, "Ob. Cit." pag. 83.

(40) "Diverse dalla capacità civile. sono altre specie di capacità giuridiche... Ma, benchè diverse, pure si trovano poste in qualche relazione rispetto alla stessa capacità civile suddetta; come nel diritto privato, cosi anche nel diritto pubblico. E quanto al diritto privato, chi sia pienamente capace per legge civile, è capace di pare per diritto commerciale. Anche analogamente le persone di età minore e le donne maritate, incapaci 
Em os numeros que a este se seguem - mais se verá a este respeito.

19. DIREITOS CIVIS (41). - Os direitos civis são o complexo das faculdades que todo o individuo possue de agir nos limites do direito privado e sob a guia e a garantia das leis positivas e dos usos que têm força de lei.

per diritto civile non avrebbero capacità di esercitare il commercio senza le autorizzazioni richieste dalla legge, eventuali e revocabili...

......

"La capacità elettorale, politica od amministrativa... e similmente le incapacità contrarie, NONN HANNO ATTINENZA COL DIRÍT'TO CIVILE (*), se non inquanto vi sieno poste in correlazione dalle leggi speciali...

"Coloro che, per diritto civile, sono capaci o sono incapaci, ritengono questa loro condizione rispettiva nei giudizi civili; cioè nel diritto pubblico giưdiziario, salva in più casi di incapacità dipendente per diritti dalla disposizione della legge, dove questa inchiede che la difesa della parte in lite sia necessariamente commessa a persone determinate". Girolamo ScalamandRè, "in" Il Digesto Italiano - Enciclopedia Metodica ed Alfabetica di Legislazione, Dottrina e Giurisprudenza" Vol. Sexto - Parte Primeira, Torino, 1888, ns. 11 a 13. Indicação bibliographica da Bibliotheca da Faculdade de Direito da Universidade de S. Paulo : K3 -. $21-1$.

(*) Os gryphos são nossos.

(41) DIREITOS CIVIS (V. "Direito"): CORREIA DE LACERDA, Diccionario Encyclopedico, 5. ${ }^{\mathrm{a}}$ Ed., pag. 966, $1 .^{\mathrm{a}} \mathrm{col}$.

“... Esta locução no plural comprehende os direitos em geral, cujo gozo a lei assegura a todo o cidadão. Estes direitos são relativos á pessoa e á propriedade...

“... Dizem-se DIREITOS CIVIS em CONTRAPOSIÇÃO a DIREITOS POLITICOS (*).

"I diritti si distinguono pure in POLITTCI e CIVILI: i primi consistono nella facoltà di participare all'esercizio del potere sovrano; i secondi riguardano il patrimonio e la famiglia". (ENCICLOPEDIA UNIVERSALE, V. "Diritto"). Indicação bibliographica da Bibliotheca Publica do Estado de S. Paulo : $3-16-144$.

(*) Os gryphos são nossos. 
São denominados CIVIS para differençal-os dos POLITICOS, que se referem ás relações do individuo com a sociedade, da qual faz parte, e que entram na esphera do direito publico.

A differença entre os DIREITOS CIVIS e os DIREITOS POLITICOS é, pois, precisamente caracterizada pelas duas fontes das quaes derivam, e nunca será possivel a sua confusão emquanto a sciencia mantiver uma perfeita distinç̧ão e uma completa separação entre o direito privado e o direito publico. Será necessario lembrar, porém, que o direito privado não é constituido somente pelos codigo civil e commercial e pelo codigo de processo civil, mas, tambem, por todas aquellas leis especiaes e por todos aquelles usos locaes que apresentam affinidade com o conteudo dos alludidos codigos, aos quaes trazem modificações e accréscimos (42).

(42) "I diritti civili sono il complesso delle facoltà che ogni individuo ha di agire nei limiti del diritto privato e sotto la guida e la garanzia delle leggi positive e di quegli usi che han forza di legge.

Son detti "civili" per DIFFERIRLI (*) dai "politici" che riguardano i rapporti dell'individuo con la società, di cui fa parte, e che rientrano nella sfera del diritto pubblico.

La differenza fra i diritti civili ed i diritti politici è quindi nettamente posta dalle due sorgenti da cui derivano, e la loro confusione non sarà mai possibile finchè la scienza manterrà una perfetta distinzione ed una completa separazione fra il diritto privato ed il diritto pubblico. Soltanto sarà necessario di por mente che il diritto privato non è costituito dai soli codici civile e commerciale e dal codice di procedura civile, ma eziandio da tutte qr lle leggi speciali e da tutti quegli usi locali che hanno affinità col cont uto di quei codici, che ad essi portano modificazioni od aggiunte, e c. e possono riferirse ai rapporti di parentela, di affinità, di legittimazione, e di successibilità; ai diritti reciproci risultanti dal matrimonio, dall'adozione e dal riconoscimento dei figli nati fuori di matrimonio; alla facoltà di ricorrere ai tribunali per ottenere giustizia o per diffendersi contro la minaccia di una ingiusta aggressione; alla facoltà di disporre per testamento, di par da testimoni negli atti pubblici, di esercitare una professione, un mestiere, il commercio e simili; infine, alla libertà di stipulare convenzioni di ogni genere, di obbligarsi e di obbligare, di rinunziare ai propri diritti già acquisti, di far valere eccezioni e decadenze di ogni genere contro coloro che vi sono incorsi e, in poche parole, di disporre liberamente della propria volontà e dei propri beni nell'ambito dei rapporti d'interessi affatti personale. Se 
Para Ch. Beudant o epitheto CIVIL é um qualificativo equivoco, que sentido não possue por si mesmo e outro não é senão o que resulta das opposições que elle facilita. Os direitos civis diz-nos o abalisado autor francez - SÃO AQUELLES QUE NÃO SÃO POLITICOS; mais precisamente, são os direitos privados, aquelles direitos que as pessôas possuem em sua simples qualidade de sêres humanos, ou por consequencia de suas relações entre si (43).

Dos direitos do homem - escreveu o grande JoÃo Mendes JUNIor -, são congenitos o direito de vida, o direito de conservaৎ̧ão e aperfeiçoamento, o direito de liberdade, o direito de defesa; são adquiridos, ou porque dimanem de proprias acções licitas, ou porque dimanem de acção de outrem, ou porque dimanem de acção propria e de outrem, - o direito de propriedade, o direito de familia, o direito das obrigações.

Dos direitos do cidadão - conceitos esses são ainda do eminente autor acima —, tomada esta palavra do seu sentido amplo, significando o individuo na sociedade civil, - são congenitos os direitos de habitação, o direito de locomoção, o direito de associação; são adquiridos, em virtude do pacto social, o direito á segurança, o direito ao julgamento, o direito á força e á responsabilidade do poder social, o direito de petição e o direito de accusação; são adquiridos, em virtude do pacto politico, o direito a formas garantidoras previamente estabelecidas, ou no mesmo pacto politico ou em leis ordinarias (44).

non che, come il diritto, subiettivamente considerato, non può concepirsi in maniera assoluta e di confini illimitati, ma in maniera relativa e tale da rendere possibile la coesistenza dei diritti di tutti, ciò che implica una reciproca limitazione, cosi i diritti civili sono anch"essi soggetti ad alcune categoriche limitazioni..." Tommaso BRUno (15 de julho de 1899). "in" Il Digesto Italiano - Enciclopedia Metodica ed Alfabetica di Legislazione, Dottrina e Giurisprudenza, Vol. IX, Parte Segunda, pag. 545, n. $^{\circ} 1$.

Indicação bibliographica da Bibliotheca da Faculdade de Direito da Universidade de S. Paulo : K3 - $21-11$.

(*) O's gryphos são nossos.

(43) Ch. Beudant, Cours de Droit Civil Français: Tome premier, L'Etat et la Capacité des personnes”, Paris 1896.

(44) Doutor JoÃo Mendes JoR.: “Ob. cit., pags. 5-6. 
Todos os direitos acima são considerados - DIREITOS INDIVIDUAES, que, no seu "Direito Publico Brasileiro", Pimenta BuEvo define: "as faculdades, as prerogativas moraes que a natureza conferiu ao homem como ser intelligente"; "os attributos essenciaes de sua individualidade"; as "propriedades suas inherentes á sua personalidade"; as "partes integrantes da entidade humana" (45).

São "direitos individuaes", porque são attributos da pessôa, isto é, da substancia individual de natureza racional e social. São correlativos oppostos aos "direitos politicos", isto é, aos direitos de eleição e de accesso aos cargos publicos, direitos que sómente se tornam "individuaes" depois de adquiridas as condições de nacionalidade e de preenchidas as condições da investidura e do exercicio (46).

A respeito desses direitos A. Esmein diz que é ponto de doutrina certo e importante que elles se oppõe aos direitos politicos - propriamente ditos (47). Sentir identico ao de nosso illustre escriptor patricio.

(45) Pimenta Bueno: Direito Publico Brasileiro, 2. ${ }^{\text {a }}$ Parte, p. 390.

(46) JoÃo Mendes JoR.: Ob. e loc. cits.

(47) “Les Droits Individuels ont reçu dans la théorie constitucionelle d'autres qualifications. Au XVIIIe. siècle, et spécialement dans les débats des assemblées de la Révolution, on les appelait souvent les "Droits Civils". Dans le cours de Droit Constitucionel qu'il a professé à la Faculté de Droit de Paris, Rossi les a appelés "Droits Publics ou Sociaux", et cette terminologie est restée très répandue en France. Mais, de quelque nom qu'on les désigne, e'est un point de doctrine certain et important qu'on les oppose aux "Droits Politiques" proprement dits. Ces derniers représentent la participation des citoyens au gouvernement, à l'administration, à la justice (par l'institution du jury): l'exemple le plus frappant est le suffrage politique. Il n'y a pas là une simple opposition de termes, mais une distinction entrainant des conséquences juridiques. Les Droits Politiques n'appartiennent qu'aux citoyens, à qui la constitution et la loi accordent la jouissance et l'exercice; ils ne sont point accordés à tous les membres de la Nation sans distinction aucune d'âge, de sexe, ou de capacité; nous avons vu qu'il en était ainsi même fondamental, le droit de suffrage. Au contraire, les Droits individuels appartien- 
nent, en principe, à tous les individus qui composent la Nation quels que soient leur âge, leur sexe, leur incapacité de fait ou même leur indignité: c'est en ce sens que tous sont également citoyens. Cela est absolument vrai de quelques-uns des droits individuels: la liberté individuelle "stricto sensu", la liberté de conscience, la liberté du culte. Pour certains autres, bien que cette legalité subsiste en tant que principe dirigeant, la réglementation légale qui leur est appliquée doit nécessairement créer un certain nombre d'incapacités. Cela provient des deux causes. Ou ces droits, par leur exercice, peuvent, en fait, constituer une véritable action politique et présenter l'équivalent indirect d'une participation à la pouissance publique: telles sont la liberté de la presse, la liberté d'association, la liberté de reunion et même la liberté d'enseignement, par laquelle on forme les futurs citoyens. Ou bien il s'agit de protéger l'individu, encore incapable en fait, contre la dommage qu'il se pouvait faire à lui même par l'abus de son droit individuel; c'est ainsi que la liberté du travail est légitimement restreinte, en certains cas, en ce qui concerne les enfants et les femmes. 


\title{
O QUE SE ENTENDE POR CAPACIDADE CIVICA OU POLITICA
}

\author{
20. CAPACIDADE CIVICA OU POLITICA \\ 21. DIREITOS POLITICOS
}

20. CAPACIDADE CIVICA OU POLITICA (48). - A capacidade em relação ao direito publico póde definir-se como em sendo a aptidão que possuem os cidadãos para tomar parte no governo da cousa publica como eleitores ou como elegiveis (preenchidas as condições essenciaes estabelecidas na Lei) a cargos diversos, gratuitos ou não, de escolha popular, administrativa ou governamental.

E' a definição de Atrmio Brunialti com pequenas alterações de nossa parte (49).

(48) "Civico" (F. J. CALdas Aulete: Diccionario Contemporaneo da Lingua Portugueza), adj."que diz respeito ao cidadão considerado na sua vida publica" ou como membro do Estado": Virtudes civicas § Patriotico: Amor "civico", Espirito "civico" F. lat. "civicus".

"Civico" (JAYMe SÉGUIER: Diccionário Prático Illustrado: adj. (lat. "civicus"). Relativo aos cidadãos como membros do Estado, etc...

"Civico" (CORREIA DE LACERDA: Novo Diccionario da Lingua Portugueza: adj. (L. "civicus", de "civis" cidadão), relativo á conservação, fé e honra dos cidadãos, ou dos filhos e defensores da patria...

(49) "La capacità in relazione al diritto pubblico può diffinirsi l'attitudine che $\mathrm{i}$ cittadini hanno di prendere una qualsiasi parte al governo della cosa pubblica come elettori, como elegibili a uffici diversi, gratuiti o pur no, di nomina popolare, amministrativa o regia". ATTILIO BRUNIALTI, "in" Il Digesto Italiano - Enciclopedia Metodica ed Alfabetica di Legislazione, Dottrina e Giurisprudenza. Loc. Cit. 
Já vimos que a capacidade eleitoral não apresenta affinidade com a capacidade civil (LIVRO III, CAPITULO I, n. 18). A capacidade eleitoral visa dar ao individuo, a que se attribue, o direito de votar, o direito de, por meio de seu voto, contribuir para a eleição (50) de alguem para algum cargo.

A essencia do voto reside na escolha consciente e livre. A consciencia do voto reside na sciencia de tres problemas:

1. quaes as necessidades actuaes do paiz;

2. quaes as providencias mais acertadas;

3. quem, entre os cidadãos, mais capaz é de dar provimento a estas necessidades.

A liberdade do voto consiste em preferir o eleitor, contra seja qual fôr o interesse, os candidatos que considere mais capazes.

Ora, a selecção dos mais capazes, para desempenhar missão essa tão alevantada, não pode ser feita senão com discernimento claro e liberdade moral. Não fosse assim e se promoveria o regimen da incompetencia e da irresponsabilidade (51).

(50) "Eleição" (F. J. Caldas Aulete, Ob. Cit.), s. f. "escolha que se faz para algum cargo, por meio de votos ou do suffragio".. F. lat. "Electio".

"Eleição" (Antonio de Moraes Silva, Ob. Cit.) s. f. o acto de eleger, escolha que se faz de alguma coisa, ou de alguma pessoa para algum officio, emprego.

"Eleitor" (F. J. Caldas AuleTe, Ob. Cit.), s. m., o que tem direito ou poder de eleger § Membro de um collegio eleitoral § F. lat. "elector".

"Eleitor" (Antonio DE Moraes Silva, Ob. Cit.), s. m. "ora" fem. "Pessoa, que tem poder, ou direito de eleger.

"Eleitor" (JAYME SÉGuIER, Ob. Cit.), s.. m. "Aquelle que elege, aquelle que está nas condições legaes de poder eleger ou de votar alguém para cargos electivos.

"Eleitor" (CORREIA DE LACERda, Ob. Cit.),ôra, s. m. ou f. (l. "elector"), pessoa que elege, ou tem direito de eleger a outrem para algum emprego ou dignidade.

(51) Professor Doutor A. DE SAMPaIo DoRIA: Principios Constitucionaes, 1926, pags. 38-39 e O que o cidadão deve saber, 1919, pags. 118-120. 
Dahi as restrições que a Constituição de 34 estatue ao exigir de todo eleitor : $10^{\circ}$ discernimento mental - que o legislador presumiu desde que o menor tenha 18 annos cumpridos (art. 108) -; 2. liberdade moral - que o nosso Pacto Fundamental julgou resguardada com as excepções estabelecidas nas letras $a), b$ ), c) e d) do $\S$ Unico do cit. art., eis-que a ignorancia e a indigencia conduzem á falta de independencia e de isenção dos exceptuados; a inclisciplina de recear-se seria se não se attendesse á situação especial em que se encontram as praças de pret; e a incompatibilidade dos que por motivo de convicção religiosa, philosophica ou politica se isentam, porisso mesmo, de onus ou serviço que a lei impõe aos nacionaes - resulta da propria condição excepcionalissima desses individuos que, fazendo renuncia da autonomia de suas consciencias, isto é, abdicando da liberdade, viciariam o voto, se delle pudessem dispôr.

Os motivos que determinaram as outras excepções abrangidas pela letra $d$ ) do § Unico do art. supra e de que tratam os arts. 107, 110 e 111 - transluzem da simples leitura destes ultimos artigos.

Como se vê bem differente é essa capacidade daquell'outra que estudámos em o n. 18 deste LIVRO III.

21. DIREITOS CIVICOS OU POLITICOS (52). - Direitos politicos são os que consistem na participação ao exercicio da autoridade publica e dos poderes que a representam; são aquelles por meio dos quaes os particulares tomam parte, directa ou indi-

(52) “DIREITOS POLITICOS" são "aquelles por cujo exercicio o cidadão, em um governo livre, toma parte nos negocios publicos (J. F. Caldas Aulete: Ob. Cit.), V. "Direito".

"I diritti si distinguono in "POLITICI" e "CIVILI": i primi consistono nella facoltà di participare all'esercizio del potere sovrano; i secondi riguardano il patrimonio e la famiglia" (Enciclopedia Universale", V. "Diritto"). Indicação bibliographica da Bibliotheca Publica do Estado de São Paulo: 3 - 16 - 144.

". Dizem-se "DIREITOS CIVIS" em CONTRAPOSIÇÃO a "DIREITOS POLITICOS" (Correia de LACERDA: Ob. Cit., pag. 966, 1. ${ }^{\text {a }}$ col. V. "Direito"). 
rectamente, no governo do paiz. Resumem-se seja ao direito de eleger ou ao de ser eleito, seja ao de ser nomeado para as funcções publicas por via das quaes se pode participar dos poderes legislativo, executivo e judiciario (53).

Eis a definição de HaURIOU: "são direitos politicos ou civicos os direitos que dão ao individuo uma participação na vida publica do Estado. Taes são o direito de suffragio, a aptidão ás funcȩões publicas, o direito de petição, o direito de ser jurado, testemunha nos actos, soldado. "(54).

O nosso grande RuY BaRBosa a respeito de "attribuições politicas" entendia serem ellas as "consideraçöes de "interesse commum", de "utilidade publica", de "necessidade" ou "vantagem nacional. " (55).

Eis juristas de renome universal a caracterizar e distinguir perfeitamente os direitos politicos dos direitos civis.

(53) “ .. Les Droits Politiques”... Ce sont ceux qui consistent, pour les particuliers, dans la participation à l'exercice de l'autorité publique et des pouvoirs qui la représentent; ce sont ceux par lesquels les particuliers prennent part, directement ou indirectement, au gouvernement du pays. Ils se résument dans le droit d'élire et d'être soit élu, soit nommé aux fonctions publiques, celles par lesquelles on participe aux pouvoirs législatif, exécutif et judiciaire". CH. BEUdant: Cours de Droit Civil Français, L'État et la Capacité des Personnes, Tome Premier, Paris, pag. 82.

(54) "Les "Droits Politiques" ou Civiques sont les droits qui donnent à l'individu une participation à la vie publique de l'État. Tels sont le droit de suffrage, l'aptitude aux fonctions publiques, le droit de pétition, le droit d'être juré, témoin dans les actes, soldat..." Maurice HaURIoU, Principes de Droit Public, 2e. Éd., pag. 380 . Indicação bibliographica da Bibliotheca da Faculdade de Direito da Universidade de S. Paulo: N8 - $15-18$. Indicação bibliographica da Bibliotheca $\mathrm{Mu}$ nicipal de S. Paulo.

\section{1. ${ }^{\circ}$ Pavimento}

Sala H F Prat -b-

Est. 12 N. ${ }^{\circ}$ de ord. 22

(55) RUy Barbosa: O Direito do Amazonas ao Acre Septentrional, 1910, Volume I, pags, 129 e segs. 


\section{CARACTERISTICOS DIFFERENCIAES}

\section{CAPACIDADE CIVIL}

1. E' a que diz respeito ao cidadão considerado no seu caracter, condição e relações PARTICULARES. (F. J. Caldas Aulete).

2. E' a aptidão de alguem para exercer por si os ACTOS DA VIDA CIVIL. (Clovis BeVilaqua).

3. A capacidade civil é differente da capacidade politica. G. SCALAMANDRÈ : "in" Il Digesto Italiano).

\section{DIREITOS CIVIS}

1. Esta locução no plural comprehende os DIREITOS EM GERAL, cujo gozo a lei assegura a todo o cidadão. (CORREIA DE LACERDA).

2. São os direitos que não são politicos. (BEUdANT).

3. Dizem-se DIREITOS CIVIS em CONTRAPOSIÇÃO A DIREIT'OS POLITICOS. (CORREIA DE LACERDA).

4. Sua acção é no DIREITO PRIVADO. (T. BRUNo, "in" Il Digesto Italiano).

\section{CAPACIDADE CIVICA}

1. E' a que diz respeito ao cidadão considerado na sua VIDA PUBLICA. (F. J. Caldas Aulete).

2. E' a aptidão que possuem os cidadãos para TOMAR PARTE NO GOVERNO DA COUSA PUBLICA COMO ELEITORES ou como elegiveis a cargos diversos. (AtTilio BrUNiaLTI).

3. Não tem ligação com o direito civil. (G. ScALAMANDRE "in" Il Digesto Italiano).

\section{DIREITOS CIVICOS}

1. São aquelles por cujo exercicio o cidadão, em um governo livxe, toma parte nos NEGOCIOS PUBLICOS. (F. J. CALDAS AUlete).

2. Referem-se ás relações do individuo COM A SOCIEDADE. (T. BRUNO, "in" Il Digesto Italiano).

3. Dizem-se DIREITOS CIVICOS em CONTRAPOSIÇÃO A DIREITOS CIVIS.

4. Entram na esphera do DIREITO PUBLICO. (T. BRUNo, "in" Il Digesto Italiano). 


\section{LIVRO IV}

O ART. 9 DO CODIGO CIVIL EM FACE DO ART. 108 DA CONSTITUIÇÃO DE 34 


\title{
CAPITULO I
}

\section{APPLICAÇÃO DAS LEIS}

\author{
22. OS DOIS CAMPOS \\ 23. A INTENÇÃO DO LEGISLADOR \\ 24. O FIM SOCIAL DA LEI \\ 25. UM PARALOGISMO A EVITAR-SE
}

22. OS DOIS CAMPOS. - Vimos em o LIVRO I a ORIGEM HISTORICA do art. 108 da nova Constituição Federal e do art. 9 do Codigo Civil Brasileiro; em o LIVRO II deparámonos com as interpretações que ao primeiro dos artigos citados dão eminentes vultos no Direito Pátrio; finalmente, em o LIVRO III - o caracteristico differencial entre "CAPACIDADE CIVIL" e "CAPACIDADE CIVICA" ou "POLITICA" - Agora, devemos reunir todos esses preciosos elementos e as fracas forças de que dispomos para - a uma conclusão chegar.

Como se deprehende de nosso trabalho - dois campos se formaram no tocante á interpretação do texto do art. 108 da Constituição de 34. De ambos os lados se apresentam insignes figuras de nossa jurisprudencia.

De um lado os que creem abrogadas as exigencias da lei civil (Codigo Civil - Art. 9) respeito ás condições da CAPACIDADE CIVIL: Pois, não se encontra apto o individuo de 18 annos completos, alistado na forma da lei, para intervir na direç̧ão dos interesses da collectividade nacional, como eleitor? Pois, comprehende-se que um individuo exerça o direito do voto e esteja ao mesmo tempo sob o pátrio poder? Pois, o facto do menor de 21 annos e maior de 18, contando com o apoio da lei, poder alistar-se, mesmo contrariamente á ordem do seu progenitor ou tutor, - não 
implica numa emancipação de facto? Pois, o seu titulo de eleitor, nesse caso, não poderá ser comparado com um diploma de escola superior? Pois, a lei politica, sendo, como é, de ordem constitucional, não é de hierarchia superior á lei civil? E assim sendo, dispondo em contrario ao principio da lei civil, — não o revoga? Não deve o direito civil ceder perante o direito constitucional?

De outro lado, os que pensam continuarem de pé todas as condições que a lei civil de 1916 estabelece quanto á CAPACIDADE CIVIL: Cumpre distinguir - dizem estes ultimos. - A CAPACIDADE CIVIL não se confunde com a CAPACIDADE CIVICA. Uma cousa é aquella; outra esta. O dever "POLITICO" não acarreta, por si só, a capacidade "CIVIL", abrogando o art. 9 do Codigo Civil e outros que versam sobre a capacidade civil ("exempli gratia" o art. 242 do Codigo Civil). Sendo differentes uma da outra, essas duas capacidades - a Constituição Federal, ora em vigor, em vez de contrariar a lei civil: confirma-a.

Como se vê, os adeptos de uma e outra interpretação, além da sua grande autoridade, apresentam argumentos taes, que lidos separadamente - é dar razão aos' que em mãos tivermos.

Defensores da maior e igual envergadura apresentam os dous sentires tornando, porisso mesmo, mais ardua nossa tarefa. Para levar a cabo esta ultima, mistér é, por conseguinte, reportarmo-nos unicamente ás idéas defendidas em ambas as interpretações, sem nos deixarmos influir pelos grandes nomes de seus patronos.

Portanto, com os parcos conhecimentos e a nenhuma autoridade que nós outros possuimos, vamos vêr se conseguiremos sahir deste difficil passo.

$\mathrm{E}$ as dúvidas? 
“... O Vérité, tu les éclaires

Seulement d'une aube qui luit. "

E para chegarmos á realização do nosso escopo, procurando fixar com exactidão o sentido da lei, quê fazer senão decompol-a, analysal-a? Quê fazer senão dispôr dos 4 elementos (o elemento grammatical, o logico, o histórico e o systematico), com os quaes poderemos - quem sabe? - vislumbrar a desejada Verdade?

Sobre o elemento grammatical e o histórico - dispensamo-nos de sobre elles escrever mais. Pelo que se encontra atraz: uma idéa já se poderia ter feito.

Vejamos os outros dous. Procuremos fazer a analyse da lei, "id est", o estudo da relação lógica em que se acham as suas diversas partes, de modo a vêr se conseguimos o seguro conhecimento do seu sentido. Procuremos, ainda, considerar os artigos por nós visados, em frente do systema geral do direito ao qual elles pertencem.

23. A INTENÇÃO DO LEGISLADOR. - A intenção do legislador não deve ser desprezada para fixar o verdadeiro sentido do art. 108 da nova Constituição. Se bem que a interpretação grammatical - como se vê dos LIVROS anteriores nos seja inteiramente favoravel : não é raro esta ultima dar maus resultados, chegando mesmo a produzir erros, o exagerado escrupulo na interpretação grammatical do significado de cada palavra. A esse respeito, ensina Dernburg (55), o texto da lei desperta em nós representações, que não são expressas pelas palavras singularmente consideradas, e que, todavia, nós reconhecemos, com precisão, como pertencentes á lei. E' o “conteúdo latente" da lei. Frequentemente succede, avisa-nos Paulus (56) que cousas que parecem reunidas por uma conjuncção copulativa, devem estar

(55) Dernburg - Pandette, trad. de Cicala, § 34.

(56) Paulus - fr. 53 princ. e $\S 1-$ De verborum significations $(50-16)$.

17 - R. F. BREETro 
separadas, e cousas que parecem separadas por uma disjunctiva devem estar reunidas... Que o digam os illustres interpretes do artigo 26 das "DISPOSIÇõES TRANSITORIAS" da Constituição Brasileira em vigôr.

Já o escrevemos - que, dos vibrantes discursos proferidos na augusta Assembléa Nacional Constituinte de 34 perante jurisperitos, jurisconsultos de nomeada e de não menos afamados homens do direito (vide ANNEXO n. 1), - constata-se:

$1^{\circ}$ que os oradores SOMENTE debateram a questão da EXTENSÃO DO DIREITO DE VOTO AOS MENORES DE 21 ANNOS E MAIORES DE 18;

2. que SOMENTE houve referencia aos cidadãos considerados COMO MEMBROS DO ESTADO;

3. ${ }^{\circ}$ que em tão grave Assembléa ninguem gizou ou siquer esboçou o não menos grave problema das consequencias que adviriam se se estivesse cogitando dos cidadãos considerados no seu caracter, condições e relações particulares.

Veja-se o nosso n. 8 do Capitulo III (Na Assembléa Nacional Constituinte de 34) do Livro I.

Bem explicito é o art. 108, aliás.

"SÃO ELEITORES" - diz elle.

O pensamento do legislador de 34 foi "no sentido do ALARGAMENTO DO CORPO ELEITORAL, fazendo intervir na escolha dos homens publicos O MAIOR NUMERO DE CIDADÃOS, tendencia essa que se revela uniformemente em tres orientações geraes : a extensão do DIREITO DE VOTO A' MULHER, a DIMINUIÇÃO DOS REQUISITOS exigiveis para a obtenção do TITULO DE ELEITOR, e O ABAIXAMENTO DO LIMITE DA IDADE" (vide ANNEXO n. 1).

Abaixamento do limite da idade - logica e naturalmente: UNICAMENTE para a obtenção do TITULO DE ELEITOR.

Mais considerações a esse respeito serão expendidas em o Livro V (CAPITULO I. "Applicações no Direito Civil”: APPLICAÇÃO N. 1). 
24. O FIM SOCIAL DA LEI. - Mas abandonemos, por um instante, o processo que já para alguns autores se afigura de archaico de inquirir da intenção do legislador (57).

Consideremos a lei, como preconiza João Mangabeira, "como formula juridica de necessidades sociaes" (58).

Consideremos o fim social da lei:

No seu recentissimo "Trattato di Diritto Civile Italiano", cujo capitulo sobre "APPLICAÇÃO DO DIREITO" foi optimamente traduzido pelo Professor da Universidade de Coimbra Manoel de andrade, diz o eminente Francesco Ferrara (59) que o jurista ha de ter sempre deante dos olhos o fim da lei, o resultado que quer alcançar na sua actuação pratica; a lei é um ordenamento de protecção que entende satisfazer certas necessidades, e deve interpretar-se no sentido que melhor responda a esta finalidade, e portanto em toda a plenitude que assegure tal tutela, procurando realizar os fins da justiça e da utilidade social (60).

E DE PaCE no seu grande livro "De l'interprétation des lois" diz: "O methodo da sciencia do direito deve ser não a deduç̧̃̃o logica, porém a induç̧ão social" (61).

(57) João Mangabeira, Em torno da Constituição, Cia. Editora Nacional, 1934, pag. 257.

(58) JoÃo MaNgabeira. Obr. e loc. cits.

(59) Francesco Ferrara, Trattato di Diritto Civile Italiano, $1 .^{\circ}$ Vol., pag. 204.

(60) “L'interpretazione giuridica, mirando all'applicazione pratica del diritto è di natura essencialmente "teleologica". Il giurista deve avere sempre di fronte agli occhi lo scopo della legge, il risultato che vuole reaggiungere nella sua attuazione pratica; la legge è un ordinamento di protezione che intende soddisfare certi bisogni, ed è da interpretari nel senso, che meglio risponda a questa finalità, e quindi in tutta la pienezza che assicure tale tutela" (Francesco Ferrara. Obr. e loc. cits.).

(61) "La science du droit n'est pas une science morale, une science formelle. C'est une science d'observation et expérimentation, comme d'ailleurs toute branche du savoir que mérite le nome de science. Que signifie dès lors, cette pseudo-souveraineté de la logique pure, cette géométrie d'une autre espèce, ce servilisme à la loi, qu'elle soit bien 
Conseguintemente a Lei Máxima de 34 deve ter uma expressão representativa, como representativa era a expressão dos delegados que a elaboraram; e esta expressão deve resultar principalmente do estudo dos interesses, das necessidades, das razões praticas de conveniencia social e bem publico que a inspiraram, e da determinação do seu escopo. Eis que a "finalidade" da lei, sendo a sua força, é a contra-prova do seu pensamento.

Ora, o fim social da Lei de 16 de julho de 1934 foi - favorecer a interessar uma parte da população brasileira - que d'antes estava excluida - para que, com o seu voto pudesse collaborar na resolução dos problemas nacionaes; para que se interessasse, mais cêdo do que d'antes, nos destinos da Patria.

Mesmo que o sentido grammatical e mesmo que a intenção do legislador - duvidas pudessem favorecer, o interprete deveria entendel-os com o pensamento e fazel-os realizar o bem que nelles deve estar contido, evitando o mal.

Augmentar o quadro eleitoral de uma nação - é uma obra meritoria. Iniciando-se mais cêdo na vida politica de sua Patria, o menor de 21 annos e maior de 18 poderá pôr em pratica o que o ardor do seu civismo ditar.

Mal - nunca poderá advir de sua intromissão na vida politica do paiz.

Mas, como frizámos mais de uma vez, satisfeitas as formalidades legaes do alistamento elle se torna UNICAMENTE "ELEITOR" Vejam-se as considerações feitas em a APPLICAÇÃO N. 1 (Applicações no Direito Civil: Capitulo I do Livro V) e que, para não cahirmos em redundancia, aqui não trazemos.

0 individuo menor de 21 annos e maior de 18 alistado na fórma da lei, em sendo ELEITOR nem por isso se torna COMPLETAMENTE CAPAZ SOB O PONTO DE VISTA POLITICO.

Antes de ter a sua integral capacidade politica diversas etapas deverão ser vencidas por elle, - eis-que:

ou mal faite, féconde ou nuisible? La méthode de la science du droit doit être non pas la déduction logique, mais l'induction social. Hors cela, il n'est qu'erreur, péril et ruine". (DE PAGE. Obr. cit.). 
I. Póde ser ELEITOR (art. 108).

II. Não póde ser deputado (art. 24).

III. Não póde ser senador (art. 89).

IV Não póde ser eleito Presidente da Republica (art. $\left.52 \S 5 .^{\circ}\right)$.

Na 1. ${ }^{2}$ etapa tem o direito de votar - DESDE OS 18 ANNOS;

Na 2.a etapa é elegivel para deputado - Só QUANDO FôR MAIOR DE 25 ANNOS;

$\mathrm{Na} 3 .^{\mathrm{a}}$ etapa é elegivel para senador e Presidente da Republica - Só QUANDO TIVER MAIS DE 35 ANNOS.

Hesitamos, devido a isso, em affirmar que o menor de 21 annos e maior de 18 annos - tenha CAPACIDADE POLITICA COMPLETA.

Que CAPACIDADE POLITICA COMPLETA é essa cujo titular - Só pode votar e NÃO PÓDE ser eleito?

Pelo texto constitucional só existiria CAPACIDADE POIIIIICA COMPLETA digna desse nome aos 35 annos: se essa capacidade é a mesma que a civil, como querem alguns autores - só aos 35 annos haveria tambem plena capacidade civil.

Mais acertado fôra dizer que o menor de 21 annos e maior de 18 annos tem CAPACIDADE PARA SER ELEITOR, "CAPACIDADE ELEITORAL", e, mesmo sob essa designação com o sentido de ser capaz relativamente AO DIREITO DE ELEGER - E Só. Entre parênthese : o mesmo, aliás, se passa com o maior de 21 annos e menor de 25 annos: o que mais uma vez vem provar que a capacidade politica nada tem que vêr com a capacidade civil - pois que esta aos 21 annos já se adquire.

Foi essa a FINALIDADE, crêmos nós, que tiveram os Srs. legisladores de 34 .

Nem poderiamos entender differentemente, eis-que “a lei é um ordenamento de protecção que entende satisfazer certas necessidades" Nunca, portanto, ella iria fazer o contrario: nunca haveria de declarar que seriam reputados maiores civilmente os menores de 21 annos e maiores de 18 annos - porque, então, seria ella uma fonte de males futuras... 
Entre 0 individuo que cáia no inciso do n. III do art. 6 do Codigo Civil e o individuo completamente normal - que gamma variada não ha! Aliás é uma pesquisa difficil, essa do discemimento. Cabe ella mais aos paes, tutores, juizes, peritos...

E' apreciando o menor, em seu desenvolvimento psychico, seus precedentes, sua educação physica e intellectual, as condições do meio em que vive, que se poderá, tanto quanto possivel, aquilatar da existencia do juizo moral pratico, que envolve o discernimento.

Sábio não teria sido o legislador se tivesse interferido na materia para dar sentido contrario á equidade.

Buscando o ideal a que se refere Appleton: tirar das formulas legaes, apesar da sua imperfeição, soluções accordes com a equidade - julgamos nós que o fim social do texto que nos preoccupa não é o daquelles que creem abrogado o art. 9 do Codigo Civil.

25. UM PARALOGISMO A EVITAR-SE. - Do exposto resulta que, pela exegese contrária á que adoptamos: para que - individuo seja ELEITOR, para que tenha CAPACIDADE CIVICA, mistér é, de accôrdo com a letra “ $a$ ” do $\S 10^{\circ}$ do citado artigo 108 da lei constitucional, SABER LeR E ESCREVER; SÓ E ELEITOR o individuo que, sendo maior de 18 annos e sabendo lêr e escrever se aliste na fórma da lei; só teriam, portanto, a CAPACIDADE CIVIL os que, maiores de 18 annos SOUBESSEM LÊR E ESCREVER (porisso que a capacidade ciril derivaria, nesse caso, da capacidade civica, a qual, por sua vez, não existiria sem aquella condição, condição "sine qua non": o saber lêr e escrever).

Os menores cujo alistamento a lei não permitte: só seriam CAPAZES CIVILMENTE - quando attingissem 21 annos (se, naturalmente, não cahissem nos incisos dos arts. 5 e 6 do Cod. Civ.).

Ora, se assim fosse: o artigo 9 do Codigo Civil passaria a ser entendido da maneira seguinte :

ART. 9. - "Aos vinte e um annos completos, ou aos 18 annos se alistado como eleitor na fórma da lei, acaba a menoridade, ficando habilitado o individuo para todos os actos da vida civil". 
Mesmo assim o texto do artigo 9 da lei civil não estaria abrogado, "id est", não teria sido annullado inteiramente e não teria perdido toda a sua autoridade; estaria "derogado" apenas, ou melhor, na esplendida technica romanista, "subrogado": eis-que fai somente alterado pelo accrescimo de mais algum pormenor.

Se expressamente ou implicitamente a nova Constituição tivesse revogado as condições da capacidade civil: nenhum argumento se poderia oppôr - porquanto : sendo ella a lei basica da organização politica, comprehende-se que ella (e principalmente nos governos presidenciaes) tenha uma preeminencia de caracter imperioso sobre as demais leis. Os seus principios constitucionaes (normas geraes e fundamentaes que inferem leis) adoptados pela Constituinte - só por outra Constituinte (ou pelo outro processo demorado constante na propria Constituição) poderiam ser reformados.

Mas nem tácita - nem expressamente pretendeu alterar as condições sobre a capacidade civil.

Para nós outros: - assim como pela nova Carta Magna os conjuges MESMO QUE ELEITORES alistados na fórma da lei NÃO PODEM dispôr, isoladamente o marido ou a mulher, dos bens immoveis (art. 235, n. I e art. 242, n. II do Cod. Civ.) eisque essas são restrições (além das outras estatuidas expressamente nos citado artigos 235 e 242) que decorrem da funcção social do casamento, tendo em vista o sagrado Instituto da Familia, o Instituto do Casamento; assim tambem, os menores de 21 annos e maiores de 18, embora alistados eleitores na fórma da lei, NÃO PODEM ser considerados capazes civilmente: - eis-que a sua relativa incapacidade resulta do PROPRIO INSTITUTO DA FAMILIA, do INSTITUTO DO PATRIO PODER (Codigo Civil, arts. 9, § 1. 379 e 392$)$. 


\section{A SOLUÇÃO}

\section{A VERDADE \\ 27. O ART. 9 DO CODIGO CIVIL BRASILEI- RO NÃO FOI REVOGADO PELO ART. 108 DA CO'NSTITUIÇÃO DE 34}

26. A VERDADE. - Diz uma parêmia mui conhecida em materia de interpretação: " $u b i$ lex non distinguit, nec interpres distinguere potest" - onde a lei não distingue, não é licito ao interprete distinguir.

Na hypothese a lei não distingue, nem explicita, nem ımplicitamente.

Não distingue explicitamente, porquanto, como fizemos vêr mais de uma vez, a nova Constituição Federal se limita a estatuir:

Art. 108. - São eleitores os brasileiros de um ou de outro sexo, maiores de 18 annos, que se alistarem na fórma da lei.

O texto, pois, só se refere a ELEITORES. A sua linguagem é inequivoca. Nelle nada se encontra que autorize um juizo contrário á solução por nós dada á presente these (Vejam-se as considerações feitas em a Applicação n. 1 - APPLICAÇõES NO DIREITO CIVIL - CAPITULO I do LIVRO V que dão remate á questão).

Implicitamente, outrosim, não distingue, visto como não surde do espirito dessa disposição, ou do systema e da harmonia da Lei constitucional, onde tal disposição se acha, motivo plausivel para entender-se que vise ella a capacidade civil.

Para fugir do texto constitucional, estabelecendo hermeneuticamente uma ampliação, e de tal natureza que elle, absolutamente, 
não consigna, seria mistér que ella fosse inspirada, ou se pudesse haver como subentendida, por consideração de ordem superior e manifesta. Como vimos - esta, justamente, é contrária áquella ampliação.

A idéa dessa ampliação não a tinha o legislador de 34 .

Esquecido não estava elle de que "um codigo não é a obra da sciencia e do talento unicamente; é sobretudo a obra dos costumes, das tradições, em uma palavra, da civilisação brilhante ou modesta de um povo. Mudam-se de repente as instituições politicas de um paiz. Mas a sociedade civil, não ha revolução que a altere de um jacto. Modifica-se por uma transformação secular" (62).

\section{O ART. 9 DO CODIGO CIVIL BRASILEIRO NÃO FOI REVOGADO PELO ART. 108 DA CONSTITUIÇÃO DE 34. -} 0 art. 108 trata do direito civico de votar; ora, essa capacidade civica attribuida ao menor de 21 annos e maior de 18, como vimos em o Livro III, é completamente diversa da capacidade civil. Aquella diz respeito ao cidadão considerado NA SUA VIDA PUBLICA ou COMO MEMBRO DO ESTADO; esta diz respeito ao cidadão considerado no seu caracter, condição e relações PARTICULARES, diz respeito ás relações dos INDIVIDUOS ENTRE SI. Se a nova Constituição trata daquella - de maneira alguma se póde nella incluir tambem esta - eis-que são DIVERSAS.

Os elementos histórico, grammatical, lógico e systematico veem em auxilio dessa interpretação.

Logo :

O ARTIGO 9 DO CODIGO CIVL BRASILEIRO NÃO FOI REVOGADO PELO ARTIGO 108 DA CONSTITUIÇÃO DE 34.

(62) Do Relatorio do Ministro da Justiça, sr. dr. José DE AlenCAR, á Assembléa Geral Legislativa, na 1.a Sessão da 14. a Legislatura. 


\section{TOMO SEGUNDO}




\section{S U M M A R I O}

Tomo Segundo:

\section{.E A PRATICA}

Duas palavras.

L I V R $\mathbf{O} \quad \mathbf{V}$

$\begin{array}{lllllllllllll}\text { Uma } & \text { advertencia } & \ldots & \ldots & \ldots & \ldots & \ldots & \ldots & \ldots & \ldots & \ldots & \ldots & 281\end{array}$

CAP. I - Applicações no Direito Civil $\begin{array}{llllllllllll}\text { Applicação } & \text { n. } & 1 & \ldots & \ldots & \ldots & \ldots & \ldots & \ldots & \ldots & 283\end{array}$

CAP. II - Applicações no Direito Commercial $\begin{array}{lllllllllll}\text { Applicação n. } & 2 & \ldots & \ldots & \ldots & \ldots & \ldots & \ldots & 288\end{array}$

$\begin{array}{lllllllllll}\text { Applicação n. } & 3 & \ldots & \ldots & \ldots & \ldots & \ldots & \ldots & \ldots & \ldots & \ldots\end{array}$

CAP. III - Applicações no Direito Penal

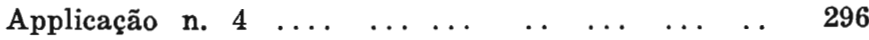
$\begin{array}{lllllllllll}\text { Applicação } & \text { n. } & 5 & \ldots & \ldots & \ldots & \ldots & \ldots & \ldots & \ldots & 300\end{array}$

A N N E X O S

Annexo n. 1 .

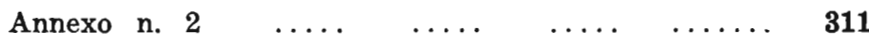

$\begin{array}{llllllllllll}\text { Annexo } & n . & 3 & \ldots & \ldots & \ldots & \ldots & \ldots & \ldots & \ldots & \ldots & 317\end{array}$

Annexo n. 4 . .

TRABALHO DE SEMINARIO 323 
... E A PRATICA 


\section{DUAS PALAVRAS}

No que concerne ao exercicio da intelligencia - deparamo-nos com 4 degraus:

$$
\begin{aligned}
& 1^{\circ} \text { - No alto da escada - A PHILOSOPHIA; } \\
& 2^{\circ} \text { - Mais abaixo - A SCIENCIA; } \\
& \text { 3.० - No outro degrau - A ARTE; } \\
& 4^{\circ} \text { - Finalmente - A PRATICA. }
\end{aligned}
$$

Se a sciencia precede a arte, a pratica segue a theoria. Muito curioso é conhecer as formas do pensamento e do raciocinio; mas se dellas não sabemos tirar regras praticas, - arido e esteril seria o seu estudo. Dá-se com o conhecimento do espirito o mesmo que se dá com o da natureza: "O que é principio, effeito ou causa na theoria, torna-se regra, fim ou meio na pratica" (BAcoN, Nov. Org., I).

Ora, uma "theoria" que não é "praticavel" - ou é falsa, ou, peló menos, é incompleta (1). Portanto, pen. samos tornar completo o presente estudo com as "APPLICAÇÕES PRATICAS" que em seguida se vão lêr. Não nos dizia IHERING (2) que - "a comparação com a experiencia é a pedra de toque de toda a theoria"?

(1) Doutor JoÃo MENDES JUNIOR, Introducção ao estudo da Pratica Forense", "In" Revista da Faculdade de Direito de São Paulo, I, 102-103.

(2) IHERING, Espirito do Direito Romano, I, 50. 
LIVRO V

APPLICAÇÕES PRATICAS 


\section{UMA ADVERTENCIA}

As questões que se podem ventilar na pratica variam ao infinito. Impossivel seria para nós, naturalmente, abordar a todas: eis-que muitas dellas, actualmente, nem escogitadas foram.

Resumil-as-emos em 3 grupos:

$$
\begin{array}{lll}
1^{\circ}-A P P L I C A C \tilde{O} E S & \text { NO DIREITO } & \text { CIVIL; } \\
20^{\circ}-A P P L I C A C \tilde{O} E S & \text { NO DIREITO COMMERCIAL; } \\
3 .^{\circ}-A P P L I C A C U \tilde{O} E S & \text { NO DIREITO PENAL; }
\end{array}
$$

Toda e qualquer outra questão que dependa de parecer attinente á duvida que offerece a interpretação do texto do art. 108 da Constituição Federal de 1934 em confronto com o art. 9 da nossa Lei Civil -, pela semelhança de motivos, poderá ser perfeitamente relacionada com uma das theses concretas adeante resolvidas: porisso que as normas que as guiam, evidentemente, são communs, e derivadas de principios geraes. 


\section{CAPITULO I}

\section{APPLICAÇÕES NO DIREITO CIVIL}

\section{APPLICAÇÃO N. 1}

Terá a Constituição Federal de 16 de julho de 1934, indirectamente, alterado a capacidade do menor de 21 annos (maior de 18 annos, porém): considerando este ultimo como CAPAZ CIVILMENTE, como se emancipado fôra - sem que se tenham realizado as hypotheses dos ns. I, II, III, IV, e V do $\S 10^{\circ}$ do Art. 9 do nosso Codigo Civil?

1. Réza a Constituição de 34 em o seu artigo 108 :

ART. 108. - "São eleitores os brasileiros de um ou de outro sexo, maiores de 18 annos, que se alistarem na fórma da Lei.

Merece relido e meditado o texto desse artigo. Bem explicito elle é : "SÃO ELEITORES"

Ora, "ELEITOR", nada mais é do que aquelle "que tem direito ou poder de eleger" (F. J. CALDAS Aulete: Diccionario Contemporaneo da Lingua Portugueza). E' aquelle que é “membro de um collegio eleitoral" (Id.). Ou, ainda, - é "aquelle que elege, aquelle que está nas condições legaes de poder eleger ou de votar alguem para cargos electivos" (JAYME SÉGUIER: Diccionário Prático Illustrado). Ou, mais ainda: "é a pessôa que elege, ou tem direito de eleger a outrem para algum emprego ou dignidade" (CoRreia DE LACERDa: "Diccionario Encyclopedico); é a "pessôa, que tem poder, ou direito de eleger" (Antonio de Moraes Silva: 
Diccionario da Lingua Portugueza); é "aquelle que elege; aquelle que está nas condições legaes de poder eleger ou de votar em alguém para cargos electivos" (CANDIDO DE FIGUEIREDo: Diccionario da Lingua Portugueza).

"SÃO ELEITORES" - estatue a Lei. Esta não diz: "SÃO ELEITORES E CONSIDERADOS MAIORES PARA OS EFFEITOS CIVIS" Não determina, ainda, "SÃO ELEITORES E CONSIDERADOS MAIORES PARA TODOS OS EFFEITOS"

"SÃO ELEITORES": outra idéa ahi não se deve incluir do contrario a interpretação estará inquinada de vicio.

2. Que a nossa nova Carta Magna contenha materia de Direito Civil - duvida não padece. E que, como nos diz Clovis BEvilaqua, dessa materia, alguma cousa, é louvavel e outra censuravel - certo é. Mas se os Srs. Legisladores de 34 não hesitaram em intercalar no grave texto constitucional regras de Direito Civil: porquê não haviam de ser claros, explicitos, no tocante a esse art. 108 - se a intenção tinham elles de considerar "CAPAZES CIVILMENTE" OS MENORES DE 21 ANNOS MAIORES DE 18?

3. 0 de que a Constituição de 34 cogita é do individuo como "ELEITOR". Só se refere, portanto, á capacidade civica ou politica que é differente da capacidade civil (Vide Livro III desta dissertação).

4. Pela simples leitura dos ARTIGOS : 5 , n. XIX, letra " $k$ "; $110 ; 113$, n. $13 ; 114 ; 168$,. — verifica-se que a Lei constitucional constantemente se refere ás leis ordinarias, as quaes, segundo aquella, devem ditar as condições de capacidade (Vide "verbi gratia": $o$ art. 113, n. 13 da nova Constituição).

5. No art. 110, por exemplo, diz: "Suspendem-se os direitos politicos: a) por incapacidade absoluta.

Qual a lei competente para dizer da incapacidade absoluta? Logica, insophismavelmente - A LEI CIVIL. 
E sendo a Lei Civil a que dita as condições de incapacidade absoluta - NAOO SERA' TAMBEM ELLA QUE HA DE DETERMINAR AS CONDIÇÕES DE CAPACIDADE RELATIVA?

6. No art. 113 , n. 13, preceitúa :

ART. 113. - "A Constituição assegura a brasileiros e a estrangeiros residentes no paiz a inviolabilidade dos direitos concernentes á liberdade, á subsistencia, á segurança individual e á propriedade, nos termos seguintes :

N. 13. - E' livre o exercicio de qualquer profissão, observadas as condições de capacidade technica e outras que a lei estabelecèr, dictadas pelo interesse publico."

Ficou aos cuidados da Lei Ordinaria, da LEI CIVIL, portanto, a determinação de "OUTRAS" CONDIÇס̋ES DE CAPACIDADE.

7. No art. 168 dispõe a nossa Lei maxima :

Art. 168. - "Os cargos publicos são accessiveis a todos os brasileiros, sem distinçẽa de sexo ou estado civil, observadas as condições que a Lei estatuir."

Vê-se, claramente, a resalva - "observadas as condições que A LEI ESTATUIR".

8. No art. 5, n. XIX, letras “ $a$ " e " $k$ ", estatúe :

ART. 5. - "Compete privativamente á União:

N. XIX, legislar sobre:

a) direito penal, commercial, civil, aereo e processual; registros publicos e juntas commerciaes;

k) condições de capacidade para o exercicio de profissões liberaes e technico-scientificas, assim como do jornalismo;" 
9. Finalmente, no art. 114:

ART. 114. - A especificação dos direitos e garantias expressos nesta Constituição não exclue outros, resultantes do regimen $\theta$ dos principios que ella adopta.

10. Collimando a Constituição e as Leis realizar os fins da Sociedade e da vida individual, seus principios devem ser entendidos no sentido mais favoravel a taes fins: ao desenvolvimento e progresso da Sociedade e ao interesse e prosperidade dos individuos, e, ṇa sua interpretação deve-se vêr o escopo pratico e social.

11. Ora, do exposto no LIVRO IV desta these - conclue-se que a concessão do voto aos menores de 21 annos e maiores de 18, visou UNICAMENTE a finalidade acima, "id est": teve um fim pratico e social, "qual o de MELHORAR E AUGMENTAR 0 CORPO ELEITORAL DO BRASIL, já de si tão precario, quer qualitativa, quer quantitativamente" (palavras do deputado Sr. almeido Camargo: Vide anNeXo n. 1).

12. Diz o art. 9 do nosso codigo civil:

ART. 9. - "Aos vinte e um annos completos acaba a menoridade, ficando habilitado o individuo para todos os actos da vida civil - 392, III, e 442, I."

Ora, se o interprete da Constituição julgar abrogado o artigo acima do Codigo Civil - não haveria uma verdadeira revolução dentro dos lares? Os relativamente incapazes abrangidos no art. 6 do Codigo Civil - alistados na fórma da Lei, não mais sujeitos estariam ao patrio poder (ou sob a chefia do marido - se tratasse da mulher casada).

Será que o legislador ousasse tanto?

Quem melhor de que os paes ou tutores - para conhecer os seus proprios filhos ou tutelados?

13. Inclinamo-nos, assim, pela interpretação mais fascinante do artigo $108 \mathrm{da}$ Constituição de $34 \mathrm{em}$ face do artigo 9 do Codigo 
Civil - extrahindo daquelle artigo, uma solução accorde com a delicadeza das consequencias que adviriam, caso se entendesse que tambem seriam capazes civilmente os individuos menores de 21 annos e maiores de 18, alistados na fórma da Lei.

14. Em conclusão, em nosso entender :

A Constituição Federal de 16 de Julho de 1934 não alterou nem directa e nem indirectamente - as condições sobre a capacidade civil estatuidas em o art. 9 do Codigo Civil.

Sem que se tenham realizado as hypotheses dos ns. I, II, III, IV e $\mathrm{V}$ do $\S 10^{\circ}$ do citado artigo do Codigo Civil - o menor de 21 annos e maior de 18 não se pode emancipar. (Const. Fed. art. 187). 


\section{CAPITULO II}

\section{APPLICAÇÕES NO DIREITO COMMERCIAL}

\section{APPLICAÇÃO N. 2}

Um menor de 21 annos e maior de 18, alistado eleitor na fórma da Lei, no exercicio regular dos direitos politicos que lhe assegura a Constituição de 34, levanta um estabelecimento commercial sem preencher as condições da Lei Commercial (art. 1. ", ns. 2 e 3), "id est" sem obter a prévia emancipação (ns. I, II, III, IV e $\mathrm{V}$ do $\S 1 .^{\circ}$ do art. 9 do Codigo Civil) e sem occultar a sua qualidade de menor de 21 annos (afastando-se, portanto, da hypothese do art. 155 do Codigo Civil).

\section{PERGUNTA-SE}

I. Adquire elle a qualidade de commerciante?

II. Está elle sujeito á fallencia?

\section{I}

1. Commerciante é a pessôa, natural ou juridica, CAPAZ de contractar, que, debaixo de uma firma ou razão social, inscripta ou não, ou de uma denominação, em seu nome e por conta propria, faz da mercancía profissão habitual. "Não o é o que o queira ser pelo simples querer. Nem o a que tal qualidade se attribua, apenas pelo se lh'a attribuir". (WaLdemar Ferreira, Questões de Direito Commercial, Segunda serie, 1932, pag. 280).

2. A capacidade commercial é fundamentalmente a mesma capacidade juridica contractual, estabelecida no Direito Civil. As 
pessôas, que, na conformidade da Lei Civil, se encontrarem habilitadas a praticar todos os actos da vida privada, têm capacidade para exercitar o commercio, salvo, é bem de ver, as excepções que a lei commercial, por motivo de ordem especial, taxativamente enumera (Codigo Commercial - Art. 2) (1).

Se assim é: - as pessoas, de ambos os sexos, capazes, na conformidade da Lei Civil, de adquirir direitos e obrigar-se por contracto, estão habilitadas a ser commerciantes.

3. Mas se a Constituição de 34 abrogou as regras da capacidade civil em relação ao menor de 21 annos maior de 18 ?

- Nesse caso, naturalmente, tudo se processaria como de um maior de 21 annos se tratasse, "id est": se elle preenchesse os requisitos apontados em o n. 1 - commerciante seria.

4. Não foi, porém, abrogado o art. 9 do nosso Codigo Civil (Vide os Livros I, II, III e IV deste trabalho).

5. Portanto: NÃO ADQUIRE ELLE A QUALIDADE DE COMMERCIANTE emquanto não observar o que preceitúa o art. 1, ns. 2 e 3 da Lei Commercial, e como a capacidade commercial é a mesma capacidade juridica contractual do Direito Civil : - para que elle adquira a qualidade de commerciante necessario será que faça cessar a sua relativa incapacidade, por um dos modos estatuidos em o $\S 1 .^{\circ}$ do art. 9 do nosso Codigo Civil.

\section{(1) CODIGO COMMERCIAL:}

ART. 2. - São prohibidos de commerciar:

1. Os presidentes e os commandantes de armas dos Estados, e os magistrados vitalicios, os juizes municipaes e os de orphãos, e os officiaes de fazenda, dentro dos districtos em que exercerem as suas funcções;

2. Os officiaes militares de $1 .^{a}$ linha, de mar e de terra, salvo se forem reformados, e os dos corpos policiaes;

3. As corporações de mão morta, os clerigos e os regulares;

4. Os fallidos emquanto não forem legalmente rehabilitados. 


\section{II}

6. O menor que se encontre nas condições da presente these $\dot{e}$ RELATIVAMENTE INCAPAZ. As obrigações que elle por acaso contrahir, NÃO SÃO NULLAS: - SÃO ANNULLAVEIS (Codigo Civil: Art. 154) (2).

"A nullidade dos actos assim praticados, todavia, não tem effeito antes de julgada por sentença. Nem póde ser pronunciada de officio: só os interessados a podem allegar, e só aos que a allegarem aproveita, salvo o caso de solidariedade, ou indivisibilidade.

Porque esses actos são annullaveis podem ser ratificados pelas partes, salvo direito de terceiro, retroagindo á data delles. 0 acto de ratificação deve conter a substancia da obrigação ratificada e a vontade expressa de ratifical-a. Excusado será elle quando a obrigação já tiver sido cumprida em parte pelo devedor, sciente do vicio que a inquinava.

A ratificação expressa, ou esta execução voluntaria da obrigação annullavel, importa renuncia a todas as aç̧ões, ou excepções, de que dispuzesse contra elles" (3).

7. Ora, só estão sujeitos á fallencia as pessôas naturaes ou juridicas que exercem a profissão mercantil - OS COMMERCIANTES (Vide ns. 1, 2, 3, 4 e 5 desta APPLICAÇÃO N. 2) (Lei n. 2024, Arts. $1 .^{\circ}$ e $20^{\circ}$ ).

Excepcionalmente, incidem em fallencia as seguintes pessoas NÃO COMMERCIANTES :

(2) CODIGO CIVIL:

ART. 154. - As obrigaçōes contrahidas por menores, entre dezeseis e vinte e um annos, são annullaveis (arts. 6 e 84), quando resultam de actos por elles praticados:

I. Sem autorização de seus legitimos representantes (art. 84) 384, V e 426, I.

II. Sem assistencia do curador, que nelles houvesse de intervir.

(3) Professor Doutor WaLdemar FgRreira, $O$ menor commerciante, n. 7 . 
10) As sociedades anonymas e em commandita por acções com objecto civil (Lei n. 2024, Art. $3^{\circ}$ ); e

$\left.2^{\circ}\right)$ Os socios de responsabilidade illimitada, no caso da fallencia da sociedade (Lei n. 2024, Art. 6..$^{\circ}$ ).

So ESSES estão sujeitos á fallencia.

8. Ora, o menor de 21 annos e maior de 18, que não se tenha emancipado por nenhum dos modos estatuidos em o art. 9 do Codigo Civil - NÃO PODE SER COMMERCIANTE (Vide ns. 1, 2, 3, 4 e 5 de I, desta APPLICAÇÃO N. 2).

9. Portanto, o menor de 21 annos e maior de 18, nas condicões da pergunta formulada no inicio desta APPLICAÇÃO N. 2 NÃO ESTÁ SUJEITO Á FALLENCIA.

10. MAS... o menor, entre 16 e 21 annos, EQUIPARA-SE AO MAIOR quanto ás obrigações resultantes de actos illicitos, em que FôR CULPADO (Art. 156 do Codigo Civil).

Logo na hypothese acima, E UNICAMENTE NESSA - estará o menor sujeito á fallencia - isto, porém: INDEPENDENTEMENTE do facto de ser elle, ou não, - ELEITOR. 


\section{APPLICAÇÃO N. 3}

A mulher casada, em face da Constituição de 34 póde, sem autorização do marido, exercer os seus direitos politicos.

\section{PERGUNTA-SE :}

Póde ella exercitar-se no commercio INDEPENDENTEMENTE da autorização marital?

Preliminarmente uma distinç̧ão cumpre fazer:

1. ${ }^{\mathrm{a}}$ - HYPOTHESE : Mulher eleitora que ao tempo de se casar, JA' ERA commerciante.

2. ${ }^{\mathrm{a}}$ - HYPOTHESE : Mulher eleitora que não se encontra nas condições ácima, "id est", que comę̧a a exercitar o commercio APÓS o seu casamento.

1. Nesta $1 .^{a}$ hypothese basta attentar-se para o que preceitúa o art. 29 do Codigo de Commercio:

ART. 29. - "A mulher commerciante, casando, presume-se autorizada pelo marido, emquanto este não manifestar o contrario por circular dirigida a todas as pessôas com que ella a esse tempo tiver transações commerciaes, inscripta no Registro do Commercio respectivo e publicada por editaes e nos periodicos do logar."

2. Neste caso não carece de autorização formal ou expressa do marido para continuar no exercicio de sua profissão.

Emquanto o marido não manifestar vontade em contrario, nos termos que a Lei determina, ella é tida e havida como commerciante. 
3. "Emquanto o marido não manifestar vontade em contrario." "

Poderá então o marido oppôr-se que continue a sua mulher, "alistada como ELEITORA na fórma da Lei", a commerciar?

- SIM; porque os artigos 29 da Lei Commercial e 9 do Codigo Civil, não foram, em nosso parecer, abrogados pelo artigo 108 da Constituição de 34 (Vide APPLICAÇõES Ns. 1 e 2).

\section{II}

1. Para a qualificação de commerciante, em nosso Direito, torna-se necessario a reunião dos seguintes requisitos essenciaes:

$10^{\circ}$ - CAPACIDADE JURIDICA;

$2 .^{\circ}$ - Exercicio de actos de commercio, em nome e por conta propria de quem o faz;

3. ${ }^{\circ}$ - Profissão habitual desse exercicio.

Se a commercialidade advem do exercicio habitual, profissional, do commercio ; se é uma questão de facto; - não obstante : conditio sine qua non é que o agente seja CAPAZ tambem.

2. Para que a mulher casada exercitar possa o commercio tres são os requisitos exigidos pelo Codigo de Commercio brasileiro :

1. ${ }^{\circ}$ - Ser maior de 18 annos;

$2 .^{\circ}$ - Ser AUTORIZADA pelo marido, por escriptura publica ;

$3 .^{\circ}$ - Serem archivados, no Registro de Commercio, os documentos comprobatorios dos dois primeiros requisitos acima.

Pelo artigo 242 do nosso Codigo Civil - qualquer que seja o regimen de bens do casamento, imprescindivel é a autorızação marital, para a mulher exercitar a mercancía. 
Pelo artigo 233 do mesmo cudigo, ainda, ao marido, como chefe da sociedade conjugal, é que compete o direito de autorizar a profissão da mulher.

3. Ora, se o art. 108 da Constituição de 16 de julho de 1934 tivesse abrogado o art. 9 do Codigo Civil: - teria tambem o mesmo feito em relação ao art. 1 , n. 4 do nosso Codigo do Commercio?

4. De accordo com o juizo desvalioso que emittimos em as paginas anteriores, julgamos nós que NÃO FOI ABROGADO 0 ARTIGO 9 DO CODIGO CIVIL.

Revogada não foi a nossa Lei Civil no ponto que analysamos; mas se o fosse, : "ipso facto" estaria abrogado o inciso n. 4, art. 1 do Cod. do commercio - eis-que "a capacidade commercial é a mesma capacidade de exercer direitos, estabelecida no Direito Civil" (4).

5. Como vimos no corpo desta obra - nem explicita, nem implicitamente o legislador de 1934 formulou idéas contrarias aos preseitos do $\S 10^{\circ}$ do art. 9 do Codigo Civil.

Nem da leitura de todo o texto constitucional se depara com elemento nenhum que ao sentir contrario poderia induzir.

6. Ora, assim sendo, a mulher casada - ELEITORA embora, que exercitar queira o commercio, necessita da autorização do marido.

7. E necessita-a porque adherindo "ao conjuncto de regras imposto pelo Estado, e que forma um todo e ao qual as partes têm somente a faculdade de adherir"..., uma vez dada a sua adhesão, sua vontade tem que se conformar com os sagrados effeitos que da Instituição do easamento decorrem.

8. Suppre, portanto, o que o nosso Codigo Civil denomina, desacertadamente, em seu art. 6, n. II, a "relativa incapacidade" por

(4) Professor Doutor HonoRIo Fernandes Monteiro, Da Mulher Casada Commerciante, 1929, pag. 11. 
meio da autorização marital (que, aliás, é revogavel) a não ser que, do acto da revogação marital, haja recurso para o poder judiciario, "id est", quando fundamentado, unicamente na hypothese do art. 245, II, do Codigo Civil.

9. Se a Constituição de 34 tivesse abrogado as condições de capacidade do art. 9 do Codigo Civil - o que succederia? - Que a mulher casada em sendo ELEITORA - não necessitaria mais daquella autorização.

Ora, se nesse sentido se tivesse manifestado o legislador de 34 - onde o bom senso? Seria possivel imaginar-se a nossa Lei Maxima, sem um motivo grave - qual o do art. 245, II do Codigo Civil - ser fonte de futuras e seriissimas desintelligencias conjugaes? (5)

10. Em nosso humilde parecer: uma unica hypothese poderia haver para que, independentemente da autorização marital, a mulher casada pudesse exercitar o commercio : - quando fosse ella supprida judicialmente (hypothese do art. 245, n. II, do Codigo Civil.

11. Em conclusão :

A' hypothese n. II desta APPLICAÇÃO N. 3 respondemos: - A mulher casada ELEITORA não poderá exercitar-se no commercio independentemente da autorização marital (com as restricções dos ns. 8 e 10 desta APPLICAÇÃO N. 3, restriç̧ões essas, porém, que independem do facto de ser ella, ou não, ELEITORA).

(5) In ambigua voce legis ea potius accipienda est significatio quas vitio caret (DIGESTO, L-1, T'-3, Frag. 19). 


\section{APPLICAÇÕES NO DIREITO PENAL}

\section{APPLICAÇÃO N. 4}

Veiu a nova Constituição Federal alterar os principios que regiam a materia sobre a responsabilidade e imputabilidade criminal dos sujeitos activos menores de 21 annos e maiores de 18 ?

1. Nesta these $\odot$ menor é o offensor ou o sujeito activo do crime :

Para constituir crime, exige-se que a violação seja IMPUTAVEL E CULPOSA.

IMPUTAR é attribuir a alguem uma acção, é leval-a á sua conta, ou affirmar que alguem é sua causa efficiente.

IMPUTABILIDADE, como abstracto de imputar, denota o complexo de condições necessarias para que uma aç̧ão possa ser attribuida ao homem como sua causa.

A CULPABILIDADE denota a falta mais ou menos grave do dever ou da obrigação por parte do agente na acção a elle imputada, "id est" de ter agido com DOLO ou com CULPA, "stricto sensu"

Se tivermos em vista a relação do agente com as consequencias de sua acção, surge, então, a idéa da "RESPONSABILIDADE"

A IMPUTABILIDADE se refere precisamente á acção, a CULPABILIDADE e a RESPONSABILIDADE ao agente, a IMPUTAÇÃO ao juizo de um terceiro. 
2. Portanto, - para constituir crime a acção ou omissão, além de IMPUTAVEL, isto é, de se poder attribuir a alguem como sua causa efficiente moral, deve ser CULPOSA, quer dizer, denotar falta mais ou menos grave do dever por parte do agente.

3. Diz o art. 27, $\S 1^{\circ}$. da Consolidação das Leis Penaes:

ARTIGO 27 - Não são criminosos:

$\S 10^{\circ}$ - os menores de 14 annos;

A idade é, pois, considerada como causa dirimente da imputabilidade.

Não obstante o caracter illicito da acção - reputa-se que falta no caso do art. 27 acima os elementos essenciaes da imputabilidade (intelligencia e vontade).

Na menoridade, que vai dos 14 annos aos 21, porém, o delinquente é tido como responsavel, salvo occorrencia de outra causa de irresponsabilidade.

Attendendo, todavia, que nesses menores a intelligencia não attingiu sua plena maturidade, o legislador estabeleceu attenuantes e moderação nas penas. Dahi a razão de ser dos arts. 30 e 65 da Consolidação das Leis Penaes (1).

4. Mostra a observação que o estado psychico do individuo, nas formas fundamentaes da intelligencia, da emotividade e da vontade, adquire sua plenitude ou maturidade após evolução lenta e continua, em coordenação com o desenvolvimento organico-phy-

\section{(1) CONSOLIDAÇÃO DAS LEIS PENAES:}

ARTIGO 30: Os menores de 18 annos, abandonados e delinquentes, ficam submettidos ao regimen estabelecido pelo decreto n. 17.943-A, de 12 de outubro de 1927, Codigo de Menores.

ARTIGO 65: Quando o delinquente fôr maior de 16 annos e menor de 18 annos, o juiz lhe applicará as penas estabelecidas no Codigo de Menores, salvo a hypothese do art. 71 do mesmo Codigo, em que serão applicadas as penas da cumplicidade estabelecidas no artigo precedente. 
siologico, e com as condições mesológicas, sociaes e de cultura, e, por isso, variando de individuo a individuo, de grupo a grupo e de povo a povo. Essa maturidade ainda diversifica, segundo se tem em vista a aptidão para acquisição das noções do BEM e do MAL ou do UTIL, variando, por isso, a IMPUTABILIDADE PENAL da IMPUTABILIDADE CIVIL. (2)

Como ensina Garraud, a lei penal, nas suas prohibições ou nas suas injuncȩões, appello faz, antes de tudo, para o senso moral, para essa immorredoira distincção do BEM e do MAL que cedo se desenvolve no homem.

A lei civil, ao contrario, procura em suas previsões regular relações mais diversas da vida social: suppõe para ser entendida, uma certa aprendizagem da vida pratica, uma apreciação da utilidade das cousas.

Ora, no homem, a noção do JUSTO surge mais cedo do que a noção do UTILL.

A LEI CIVIL dá uma importancia tão grande a este facto de observação, que declara o menor responsavel pelos seus delictos ou quasi delictos civis, ainda que lhe seja permittido fazer annullar suas obrigações convencionaes, desde que prove ter sido lesado. (Vide: Codigo Civil, arts. 155-158).

Dahi porque a MAIORIDADE PENAL é fixada antes da MAIORIDADE CIVIL ṇas differentes legislações (3).

5. Do exposto se conclúe que - mesmo que revogado tivesse sido o art. 9 da nossa lei civil, mesmo que sobre elle tivesse exercido influencia a nova Constituição: facto certo é que - para os EFFEITOS PENAES, de maneira alguma affectaria nem modificaria a concepção anterior que dominava a materia: eis-que a MAIORIDADE PENAL é fixada ANTES da MAIORIDADE CIVIL.

(2) Vide: Galdino Siqubira: Direito Penal Brazileiro, Vol. I, Parte Geral, pag. 354.

(3) Galdino Siqueira: Ob. e loo. cits. 
6. Na propria MENORIDADE CIVIL, que vai dos 14 annos aos 21 annos, o delinquente é tido como RESPONSAVEL, - salvo occorrencia de outra causa de irresponsabilidade.

7. Mas a Constituição de 34 não revogou o art. 9 do Codigo civil (Vide considerações "aliunde")

8. A Constituição Federal de 16 de julho de 1934 tambem não veiu alterar os principios que regiam a materia sobre a responsabilidade criminal dos sujeitos áctivos menores de 21 annos e maiores de 18 annos : o conceito a se lhes applicar é o do n. 6 desta these. A lei, em relação a elles considera, porém, o crime como revestido de circumstancia attenuante: é o que preceitua a Consolidação das Leis Penaes em o seu Art. 42, § 11 :

ARTIGO 42 - São circumstancias attenuantes :

$\S 11$ - Ser o delinquente maior de 18 annos e menor de 21 annos (4).

(4) Disposiç̄es do art. 76 do Codigo de Menores. 


\section{APPLICAÇÃO N. 5}

As leis penaes consideram como AGGRAVANTE (violencia presumida, violencia inductiva) de certos crimes - o facto de ser MENOR o sujeito passivo do crime.

\section{PERGUNTA-SE :}

Perante a nova Constituição de julho de 34 foi alterado esse conceito na apuração da responsabilidade criminal do agente do delicto, em relação aos sujeitos passivos menores de 21 annos e maiores de 18 ?

1. Nest'outra these o (a) menor é o (a) offendido (a) ou o sujeito passivo do crime:

Se a questão tratada na Applicação anterior é assaz importante e delicada, - muito mais o é nest'outro caso. Materia essa tão impressionante que, com toda certeza, não seria ella resolvida na augusta Assembléa Constituinte de 33-34, sem que não houvesse alguma discussão ao pretenderem intercalar, quer directa, quer indirectamente, um ou outro texto que a ella se pudesse referir.

2. Para certos e determinados crimes, elemento de importancia - capital mesmo, ás vezes, - é o de se saber se se trata de VICTIMA MENOR ou MAIOR.

$\mathrm{Na}$ Applicação N. 4 vimos a hypothese de SER MENOR o SUJEITO ACTIVO ou AGENTE do crime. Agora, trata-se do MENOR como em sendo o SUJEITO PASSIVO ou o OFFENDIDO pelo crime.

3. Supponhamos que tivesse sido revogado implicitamente o artigo 9 da nossa lei civil. Mesmo assim - nem por isso seria 
eliminada a concepção que sobre a responsabilidade e imputabilidade fazem os nossos codigos modernos.

4. Teem cabimento aqui tambem as considerações expendidas — pouco ha - em o n. 3 da Applicą̧ão anterior (a de n. 4).

5. Que em direito penal (para nós outros - mesmo no direito civil encontram applicação as idéas que vamos expôr) a questão é delicadissima: duvida não ha.

Todas as nossas leis sociaes teem em vista proteger a inexperiencia, a ingenuidade dos menores contra os enganos e fraudes dos adultos.

Será que, por um acto de emancipação - mesmo satisfeitas as exigencias dos incisos do $\S 10^{\circ}$ do art. 9 do Codigo Civil será que esses menores deixam, dahi para o futuro, de necessitar da protecção especial da lei contra aquellas fraudes, contra aquelles enganos?

Um exemplo nunca é demais: U'a menor de 21 annos e maior de 18, solteira, póde ser emancipada por um qualquer dos modos estatuidos em o $\S 10^{\circ}$ do art. 9 do cod. civil; supponhamos pelo n. I. O pae, doente, fez cessar a sua - della - relativa incapacidade, porque, sendo ella habil costureira, intelligente e possuindo tino commercial: poderia muito bem montar uma officina de costura.

Eis que, num negro dia, torna-se a moça sujeito passivo do crime previsto no art. 267 da nossa Consolidação das Leis Penaes. Pergunta-se: Não é de uma immoralidade aviltante a do offensor que, para justificar o delicto, ou, pelo menos, para vel-o diminuido no tocante á responsabilidade que elle acarreta - allegar a emancipação da victima?

Isto é grave porque é atroz; mas ainda haveria cousa mais grave :

E, então - se a offendida não foi nem emancipada por nenhum dos modos estabelecidos em o $\S 1 .^{\circ}$ do art. 9 do cod. civil: mas se ella fôr ELEITORA?

- Será moral o criminoso poder allegar a emancipação da victima. por via constitucional?... 
Teria vindo o art. 108 da nova Constituição em auxilio de intentos criminosos?

Pobre offendida!

6. Não! - Que pudesse ter o texto constitucional de 34 perante as leis civis e penaes dous sentidos: Não se deve preferir aquelle que esteja mais de accordo com os sentimentos de humanidade, de moralidade, e com os preceitos da "aequitas", procurando vêr sempre no direito a influencia do "honeste vivere"?

Sim, devemos tirar das formulas legaes, apesar da sua inevitavel imperfeição, soluções accordes com a moral e a equidade ("jus est ars boni et aequi"). Já não nos dizia Paulus e Ulpianus que: "In omnibus quidem, maxime tamen in jure aequitas spectanda est"? (1) e: "Placuit in omnibus rebus proecipuam esse justitiae acquitatisque quam stricti juris rationem" (2)

7. Dous accordams da 1. ${ }^{2}$ Camara da Côrte de Appellação de São Paulo, e que vão em Annexos no fim deste trabalho (Annexos ns. 3 e 4), dizem ser falsa a these de que, em face do art. 108 da actual Constituição Brasileira, a menoridade termina aos 18 annos, em direito penal e em direito civil. Continúa em vigor para os effeitos da legislação civil e penal - dizem elles ainda - de accordo com o art. 187 da nova Constituição, a regra segundo a qual termina aos 21 annos completos a menoridade.

Que a solução nelles dada se nos afigura certa - é verdade. Mas, na publicação onde os lêmos (Vide os Annexos Cits.), não veem as razões que motivaram aquella $\mathrm{D}$. decisão: e o que acima está apenas é o resultado dos accordams.

8. Para nós outros: A lei civil não foi revogada: é o que pensamos ter demonstrado nos capitulos anteriores.

(1) Paulus, fr. $90-$ de reg. jur. (50-19). Ulpianus, fr. $4 \S 1$ - de eo quod cert. loc. (13-4).

(2) Codigo, 8 - de jud. (3-1). 
9. E a actual Constituição em nada veiu modificar o capitulo sobre a responsabilidade e imputabilidade criminaes:

$1^{\circ}$ - porque - o legislador não teve essa intenção;

$2^{\circ}$ - porque - se assim não fosse a lei constitucional seria contra o bem-estar geral e permanente da sociedade e do individuo, e, no caso abordado, contra aquella classe que maiores solicitudes della devia esperar: OS MENORES ;

$3 .^{\circ}$ - porque - a capacidade civica que a Lei Máxima de 34 confere aos individuos menores de 21 annos e maiores de 18 - nenhuma attinencia pode ter com a complexa e delicada questão da responsabilidade e imputabilidade criminaes, eis-que: mesmo nos terrenos civil A penal ha uma differença profunda entre a IMPUTABILIDADE' PENAL e à IMPUTABILIDADE CIVIL, entre a RESPONSABILIDADE PENAL e a RESPONSABILIDADE CIVIL (Vide N. 3 da Applicaçãa n. 4).

$4^{\circ}$ - porque - para os effeitos da lei criminal não influe a emancipação civil, resultante do casamento e de outros factos previstos no $\S 1 .^{\circ}$ do art. 9, do Codigo Civil (Vide - Galdino Siqueira, Ob. Cit., pag. 363).

$5^{\circ}$ - porque - a maioridade penal sendo fixada ANTES da maioridade civil e sendo gravissimas e sensibilissimas as questões sobre essa materia: - no texto constitucional deveriam ter apparecido normas PRECISAS, CONCRETAS, CERTAS sobre o assumpto (seria invadir o campo do direito penal: mas não invadiu a Constituição de 34 TODOS os campos?); ora, nós percorremos toda a nova Constituição e não encontrámos um unico texto que permittisse, quer implicita, quer explicitamente, fazer entender que tivesse sido alterado o conceito da 
RESPONSABILIDADE e da IMPUTABILIDADE no direito penal.

Portanto,

10. Continuam em vigor as mesmas leis que regiam a materia penal antes da promulgação da Constituição de 16 de julho de 1934 (Art. 187 desta ultima). 
ANNEXOS 


\section{$\begin{array}{lll}A & N \\ N & E X O & N\end{array}$}

DA ACTA DA 148 ¿ SESSÃO ORDINARIA DA ASSEMBLEA CONSTITUINTE. SESSÃO DE 21 DE MAIO DE 1934.

Achavam-se presentes ao ter inicio a Sessão, que foi presidida pelo Snr. Antonio Carlos, 168 deputados. A acta foi lida e approvada sem observações.

\section{O DIREITO DE VOTO AOS MENORES DE 18 ANNOS}

Dando por terminada a votação do capitulo referente á Defesa Nacional, o Presidente annuncia o capitulo de "Direitos e Deveres". O Snr. Fernando de Abreu levanta uma questão de ordem, que é logo resolvida pela Mesa. Annunciada a votação, os titulos do capitulo são approvados, sem prejuizo dos destaques. 0 primeiro desses destaques, requerido pelo Snr. Medeiros Netto, é do artigo $3 .^{\circ}$, para ser incluido, em seu logar, o n. 138 do projecto, eliminando-se a letra " $d$ " e as palavras finaes da letra " $a$ ". O Snr. Marques dos Reis fala encaminhando a votação. Lembra que o artigo 3..$^{\circ}$ enumera as condições para ser eleitor, incluindo entre os eleitores os universitarios maiores de 18 annos. $O$ artigo 138 supprime, no entanto, esta regalia e S. Ex., como relator, em seu parecer mostrou-se contrario á concessão do voto aos menores e aos universitarios. O Snr. Abelardo Marinho é favoravel á concessão e em seguida o Snr. Almeida Camargo, encaminhando a votação, pronunciou o seguinte discurso:

"Snr. Presidente - Desde a commissão do Itamaraty até esta Assembléa tem-se evidenciado o desejo de augmentar o nosso corpo eleitoral, estendendo o direito de voto a menores de 21 annos, contrariamente ao que dispunha a Constituição de 91. 
Assim, appareceu o ante-projecto com o minimo de 18 annos sem outras considerações, senão a de saber ler e escrever; assim appareceram, nesta casa, varias emendas no mesmo sentido, entre as quaes lembro as dos meus nobres collegas e amigos, deputados Negreiros Falcão, Abelardo Marinho e Aloysio Filho. Tambem eu tive a honra de apresentar uma, defendendo-a desta tribuna emenda não da Chapa Unica, mas subscripta pela grande maioria de seus membros.

Com a exiguidade de tempo de que disponho, não repetirei aqui toda a serie de argumentos, que militam em favor da idéa e que expendi da tribuna, ouvido sem a menor objecção do plenario e que mereceram a acolhida mesmo da pequena commissão, como se poderá verificar do avulso.

Lembro apenas que meu unico intuito (1), assim como os dos demais propositores de emendas semelhantes, foi o de melhorar 0 corpo eleitoral do Brasil, já de si tão precario, quer qualitativa, quer quantitativamente. Demonstrei, á luz das estatisticas que, entre 40 milhões de habitantes, apenas um milhão tem, como o affirmou Gilberto Amado, uma noção embora summaria das coisas. Pois foi para augmentar este numero, melhorando.o tambem em qualidade, pois os estudantes, embora com menos de 21 annos valem (falo em vantagem eleitoral) infinitamente mais que os cidadãos que sabem apenas ler e escrever - que apresentamos a nossa emenda. Queremos eleitores. Não queremos votantes.

Argumentei ainda mais Snr. Presidente, naquella occasião, que acceitando a emenda, nada mais faria o plenario que acompanhar as tendencias das democracias de post-guerra, no sentido do alargamento do seu corpo eleitoral, fazendo intervir na escolha dos homens publicos o maior numero de cidadãos, tendencia essa que se revela uniformemente em tres orientações geraes : a extensão do direito de voto á mulher, a diminuição dos requisitos exegiveis para obtenção do titulo de eleitor, e o abaixamento do limite da idade.

E ainda mais, Snr. Presidente, mostrei o profundo erro e a profunda injustiça da rejeição da emenda: erro que afasta das urnas exactamente os mais moços, aquelles que, como o demonstra a histo-

(1) Os gryphos são nossos. 
ria, têm nos periodos de revolução, por isso mesmo que não se amargaram nas pseudo-derrotas, nem se embriagaram com as falsas victorias, o verdadeiro sentido revolucionario...

O Snr. Lengruber Filho - Aliás não são apenas os academicos : todos aquelles que, na mocidade, estão promptos a defender-nos.

O Snr. Almeida Camargo - .injustiça que despede das urnas aquelles mesmos que sempre foram os pioneiros de todas as nossas campanhas civicas.

O Snr. Irineu Joffely - Quanto á Parahyba, dou o meu testemunho disso em 1930.

O Snr. Almeida Camargo - .Aquelles que vamos buscar para nos acompanharem nas propagandas eleitoraes, aquelles que applaudimos quando, de armas na mão, vão reivindicar assim as nossas convições politicas.

Que se argumenta de mais forte contra a idéa? Que os estudantes são mais livres, que não estão presos como nós (o que é inevitavel na vida publica) a compromissos ou a amizades? Tanto melhor, Snr. Presidente.

O Snr. Abreu Sodré - Aliás isso nelles é qualidade.

O Snr. Almeida Camargo - .Que a sua interferencia na politica vae prejudical-os nos estudos? Mas todos os estudantes fazem politica, tenham ou não tenham o direito do voto. Fazem a nossa politica, em nosso beneficio e fazem a politica dos partidos academicos ás vezes mais violenta, mais apaixonada, mais pessoal.

O Snr. José Carlos - Sempre mais desinteressada.

O Snr. Almeida Camargo - . Que os estudantes pendem mais para as idéas extremistas? Mas será o voto a arma das idéas extremistas?

Não comprendo, Snr. Presidente, como se possa rejeitar o ar. tigo da pequena commissão baseado em nossas emendas. Confio no alto criterio e na sabedoria da Assembléa. Não comprehendo tambem, Snr. Presidente, que a adopção pleiteada pelos illustres "leaders" das chamadas bancadas de coordenação corresponda a uma verdadeira coordenação, pois entre as tendencias extremadas da Assembléa ella opta por um extremo e, portanto, não coordena. As nossas emendas, Snr. Presidente, equidistantes dos que querem o limite minimo de 21 annos, como se dispunha na Constituição de 91 
e dos numerosos Snrs. deputados que o abaixam para 18, é que constituem na nossa opinião e com a devida licença do nobre "leader" da maioria, as verdadeiras emendas de coordenação".

Falam a seguir os Snrs. Henrique Dodsworth, Fernando de Abreu, Fernando de Magalhães, Martins Véras, Cesar Tinoco, Accurcio Torres e J. J. Seabra. Requerida preferencia para a emenda é ella approvada. A bancada paulista, em sua maioria, votou a favor, dirigida pelo Snr. Alcantara Machado.

A emenda approvada teve como signatarios os Snrs. deputados José de Almeida Camargo, Carlota P. de Queiroz, Theotonio Monteiro de Barros, Cincinato Braga, Plinio Corrêa de Oliveira, Mario Whately, Manuel Hippolito do Rego, Alexandre Siciliano, Ranulpho Pinheiro Lima, Rodrigues Alves, Barros Penteado, Pacheco e Silva, Roberto Simonsen, Abelardo Vergueiro Cesar, Cardozo de Mello Netto, José Ulpiano e Abreu Sodré.

E depois debatida a emenda do Snr. Aloysio Filho, que amplia o direito de voto aos brasileiros em geral de um e de outro sexo maiores de 18 annos, alistados na fórma e sob as condições que a lei determinar. A emenda é dada como rejeitada. Pedida verificação de votação apura-se ter a emenda sido approvada por 96 votos contra 94. (2)

(2) Vide Diario da Assembléa Nacional Constituinte, Jornal do Commercio, do Rio de Janeiro, e O Estado de S. Paulo de Terça-Feira, 22 de Maio de 1934. 


\section{$A N \mathrm{NEXO} N$}

\section{CONSELHO DA ORDEM DOS ADVOGADOS}

A inscripção no quadro da Ordem dos Advogados será permittida á mulher casada sem autorização expressa do marido, embora tendo ela os requisitos regulamentares?

Tal é a questão, levantada no Conselho da Ordem, secção de S. Paulo, uma vez que o Codigo Civil Brasileiro dispõe no seu :

"Art. 242, n. VII - A mulher não póde, sem autorização do marido, exercer profissão"

Haverá dissonancia entre o Regulamento da Ordem (Decretolei n. 22.478, de 20-2-1933) e o Codigo Civil, de modo a ter sido este derrogado por aquele, que lhe é posterior?

A Constituição Federal de 16-7-1934, terá, indirectamente, alterado a capacidade da mulher casada, para o efeito de dispensar a autorização marital no caso em apreço?

A advocacia será uma profissão das compreendidas no art. 242, n. VII, do Codigo Civil?

Tais são as questões concorrentes.

Comecemos pela ultima :

A advocacia será uma profissão?

Sim, é. Di-lo o Regulamento da Ordem, entre outros, nos seus arts. $18,20, \S \S 1 .^{\circ}, 4 .^{\circ}$ e $7 .^{\circ} ;$ e, positivamente, quando afirma no seu 
"Art. 21. - A inscrição no quadro da Ordem, comprovada pela carteira de identidade, autoriza o exercicio da "profissão"

E no

"Art. 25, n. I. - São direitos dos advogados: exercer a "sua profissão".

De conseguinte, a mulher, inscrita no quadro, torna-se uma "profissional" da advocacia.

As leis creadoras da Ordem dos Advogados do Brasil não pretenderam retirar á classe o carater de profissão. Isso foi claramente expresso, entre outros (e bastariam os textos supra transcritos) no parecer, exposição de motivos, do principal autor da lei, o ilustre atual bastonario, Dr. Levi Carneiro, com apoio de outras autoridades, que citou, por exemplo, o conceito de LABAND, invocado anteriormente por Aureliano Leal:

"Cette "profession" unit en elle deux situations qui, d'ordinarie, sont absolument séparées et semble même inconciliables: l'accomplissement de fonctions publiques et l'exercice d'une "profession privée".

"L'activité "professionelle" des avoués est done nécessaire a l'État. C'est dans ce sens qu'il faut con. sidérer l'activité "professionelle" de l'avoué comme une fonction publique"

Profissão superior, nobre, necessaria á civilização, colaboradora na obra social, não ha duvidar, mas sempre "profissão", motivo pelo qual, tambem e desde remota éra, se lhe atribue um caráter suplementar de "munus" publico, como bem disse o Supremo Tribunal Federal :

"A advocacia, como "profissão" de postular em juizo, não é um simples mandato judicial, mas envolve um "munus" publico com responsabilidade funcional (art. 209, do Cod. Penal)", (in Rev. do Sup. Trib., vol. 21, pag. 254).

O lucido Pereira e Souza define:

"advogar é exercer o "oficio de advogado" 
E', "oficio", ensina Aulete, é "profissão, mistér, modo de vida, ocupação". E' indiscutivel, portanto, que a advocacia é uma profissão. Possuir a inscrição e a carteira da Ordem é adquirir o direito á "profissão", que póde ser isolada, ou acumulada a outras, que póde ser permanente, ou esporadica, mas sempre profissão.

\section{II}

Ora, o Codigo Civil, art. 242, n. VII, proibe á mulher exercer "qualquer profissão" sem autorização do marido, não exeptuada a da advocacia. Porque? Explicou o codificador, Clovis Beviluaqua, na sua observação ao texto:

"Esses encargos acarretam responsabilidades que podem comprometer os bens do casal, e exige cuidados, que podem prejudicar a direção interna do lar; "quer a lei que o chefe da familia decida da oportunidade de aceitá-los" As mesmas razões procedem quanto á "profissão da mulher" (Vol. 2, pag. 135).

Nada mais sensato, porque, em relação á advocacia, como disse a "Neue Freie Presse", de Viena, apreciando o grande pequenino livro de Edmond Picart, "Paradoxe sur l'Avocat":

"Dans aucune carrière le contraste entre les exigences véritables, souvent brutales de la vie, et l'ideal rêve n'apparait d'une manière aussi saisissante, que dans la "profession" d'avocat"

E, Edmond Picart, enumerando as qualidades que deve ter o advogado, escreve :

"la faculté de se passioner; il doit avoir la "bosse" de la combativité; les idées de calme et d'impartialité inalterables sont ici hors de saison. Ce sont les eunuques de la profession qui ont parfois tenté de les mettre à la mode"

Ora, a mulher, mãe de familia, esposa, creatura destinada a finalidades superiores, raramente combativa, infensa ás brutalida- 
des da vida, nem sempre poderá exercer a profissão de advogado sem graves prejuizos a ela propria, á sua familia, ao lar, aos filhos, ao marido, etc., razão pela qual é do marido o dever de autorizar, ou de negar, a autorização, como chefe da sociedade conjugal. Tenho por justificado o principio do texto civil, que não foi derrogado pelo Regulamento da Ordem dos Advogados.

\section{III}

Derrogado não foi, dissemos, porque, ao contrario, foi confirmado, pois, o art. 13 , réza :

"Para inscrição no quadro dos Advogados da Ordem é necessario, "além dos requisitos legais de capacidade civil"

Exigencia que se repete no art. 14 para os provisionados e solicitadores.

Que é a "capacidade civil"? E' a faculdade de gosar e usar de direitos individuais ou patrimoniais e o dever de cumprir obrigações civis, regidos os direitos e as obrigações pelo direito privado contido no Codigo Civil. Difere em muito da capacidade "politica", regida não pelo Codigo Civil mas sim pelo direito publico e leis especiais, porque, como ensina Clovis Bevilaqua : - "o Codigo Civil só se ocupa das relações de ordem privada; os direitos e as obrigações de ordem politica não entram na sua esfera, como dela se acham excluidas as relações de Direito internacional"

Em regra, o ser humano é capaz de direitos e obrigações na ordem civil (art. 2 do Codigo). Mas, o exercicio dos direitos, resultante dessa capacidade, póde sofrer limitações resultantes da idade, do "sexo", do estado ou da saude do titular. Eis porque o nosso Codigo, no art. 5, especificou os casos de incapacidade absoluta, e no art. 6, os de incapacidade relativa, entre os quais aí vemos o da "mulher casada", enquanto subsistir a sociedade conjugal". E no art. 242 detalha essa incapacidade da mulher casada para certos átos, inclusive o de exercer profissão. 
A Constituição Federal, ora em vigor, em vez de contrariar o exposto, o confirma. Realmente, no Capitulo "Dos Direitos e Garantias Individuais", artigo 113, n. 13, dispõe :- "E' livre o exercicio de qualquer profissão, observadas as condições de capacidade técnica e oUTRAS QUE A LEI ESTABELECE, ditadas pelo interesse publico". Deixou, pois, á lei ordinaria estabelecer "outras" condições de capacidade. Que lei? A lei civil commum, no caso, o Codigo Civil, quando regula a capacidade da mulher e, no art. 242, traça a condição do consentimento marital para o exercicio das profissões.

A Constituição creou o dever de alistamento eleitoral e voto obrigatorio para as mulheres que exercerem função publica remunerada (art. 109). Esse dever "politico", assim como o direito de ser eleita, ou a elegibilidade da mulher, não acarreta, por si só, a capacidade "civil", derrogando o art. 242 do Codigo Civil. Tanto assim que 0 art. 5, n. XIX, letra “ $k$ ”, da Constituição dá competencia privativa á União para legislar sobre as condições de capacidade para o exercicio de profissões liberais, entre as quais condições está, já legislado pela União no Codigo Civil, art. 242, a autorização marital para a mulher exercer a advocacia.

Deu á mulher o direito de exercer cargos publicos, eletivos ou não, mas com a ressalva (art. 168): "observadas as condições que a lei estatuir" Enfim, estão de pé todas as condições, que as leis estabelecerem, quanto á capacidade civil, que não se confunde com a capacidade "politica". Se a mulher, hoje, no Brasil, goza de capacidades politicas, outorgadas pela Constituição, entretanto e não obstante, ninguem poderá sustentar, de juizo perfeito, por exemplo, que a mulher possa, "sem autorização do marido", alienar ou gravar imoveis, alienar direitos reais seus, aceitar ou repudiar herança ou legado, em contrario ás restrições que o Codigo Civil, art. 242, lhe impoz. Quer dizer que todas as condições desse texto civil continuam em vigor, inclusive, pois, o consentimento do marido para exercer a mulher qualquer profissão. A Constituição não alterou de uma virgula as condições de capacidade "civil" da mulher. Sentio, naturalmente, sensatamente, que a mulher não é in- 
ferior, nem superior, nem igual ao homem, porque é apenas “deliciosamente diferente", na frase espirituosa de não sei quem. A sintese supra bastará para a seguinte:

\section{$\nabla$}

\section{CONCLUSÃO}

- A) - A Ordem dos Advogados tem que respeitar os arts. 13 e 14 do seu Regulamento, exigindo prova dos requisitos legais de "capacidade civil" para a inscrição no quadro.

B) - A mulher casada, que pretender inscrição, deve exibir autorização expressa de seu marido, ainda que por instrumento particular autenticado.

C) - Essa autorização poderá ser suprida, perante a Ordem, na forma e nos casos do art. 247, § un. do Codigo Civil, e judicialmente nos do art. 245 , n. II. São de observar os preceitos, que forem aplicaveis, dos arts. 244-255 do mesmo Codigo.

E' o meu parecer, salvo melhor juizo.

São Paulo, 28 de janeiro de 1935.

J. M. de Azevedo Marques.

N. B. : Este parecer do Presidente da Ordem, na Seç̧ão de São Paulo, foi aprovado.

(2) Vide Revista de Critica Judiciaria, Anno XII - Vol. XXI, ns. 2-3, Fevereiro e Março de 1935. Pags. 169 a 173. 


\title{
A N N E X O N 3
}

\author{
ACCORDAM
}

\section{PRIMEIRA CAMARA DA CÔRTE DE APPELLAÇÃO}

Em face do artigo 108 da Actual Constituição, a menoridade em Direito Civil e Penal não termina aos 18 annos de idade.

TAUBATÉ - 6.895 - Dr. Theodomiro Piza. - Recorrente a Justiça Publica. - Recorrido: Cornelio Gomes França. "Vistos, expostos e discutidos estes autos de recurso crime n. 6.895, da Comarca de Taubaté, em que são recorrente a Justiça Publica e recorrido Cornelio Gomes França, accordam em 1. ${ }^{\text {a }}$. Camara da Côrte de Appellação, por votação unanime, dar provimento ao recurso para julgar procedente a denuncia e pronunciar o recorrido como incurso nas penas do artigo 267 do Codigo Penal, sujeitando-o a prisão e livramento, sendo o seu nome lançado no ról dos culpados. Estão demonstrados todos os elementos do crime de defloramento: a menoridade da victima, pelas certidões de fls., 8 e 38 ; a seduç̧ão, pelas declarações da offendida, de sua mãe e do proprio réu, que confessa ter sido noivo da mesma, com quem teve relações carnaes varias vezes. $\mathrm{O}$ crime em sua materialidade, está plenamente provado pelos autos de corpo de delicto. E' falsa a these de que, em face do art. 108 da actual Constituição Brasileira, a menoridade termina aos 18 annos, em Direito Penal e em Direito Civil. Deante do exposto no art. 187 da Lei Fundamental, continuam em vigor as disposições do Codigo Penal, inclusivé a do 
artigo 267, como bem fundamentou o Dr. Promotor Publico em suas razões de fls. 53. Custas afinal. São Paulo, 14 de fevereiro de 1935. - Theodomiro Piza, P. e relator. - J. C. de Azevedo Marques. - Arthur de Almeida. (3).

(3) Vide Diarto Official do Estado de S. Paulo, de Quinta-Feira, 14 de março de 1935, Pag. 21. 


\title{
$A N$ N E X O N $\quad 4$
}

\author{
ACCORDAM
}

\section{PRIMEIRA CAMARA DA CÓRTE DE APPELLAÇÃO}

\author{
MENORIDADE - QUANDO TERMINA - \\ PRECEITO CONSTITUCIONAL:
}

Continua em vigor, para os effeitos da legislação civil e penal, de accordo com o art. 187 da nova Constituição, a regra segundo a qual termina aos 21 annos completos a menoridade.

COMARCA DE AREIAS - 8.987 - Dr. José Gomes Roseira, impetrante - Benedicto Moreira da Silva, paciente. "Vistos, expostos e discutidos estes autos de habeas-corpus n. 8.987, de Areias, em que é impetrante o Dr. José Gomes Roseira e paciente Benedicto Moreira da Silva, accordam em 1. ${ }^{a}$ Camara da Côrte de Appellação, por votação unanime, negar a ordem e condemnar o impetrante nas custas.

Está preso o paciente por ter sido pronunciado como infractor do art. 267 da Consolidação das Leis Penaes. Allega-se que a prisão é illegal : a) porque, apesar de não ser a offendida pessoa miseravel, foi movido o processo, não por sua mãe e representante legal, mas pelo promotor publico; b) porque o facto delictuoso imputado ao paciente occorreu após a vigencia da Constituição Federal de 16 de julho de 1934, eujo art. 108 estatue que aos 18 annos termina a menoridade. Tendo a victima 20 annos cumpridos -prosegue o impetrante - segue-se que, consoante os arts. 407 e 274 da referida Consolidação, correu a acção eivada de nullidade, visto ser o ministerio publico parte illegitima para movel-a. 
Não procede a argumentação do impetrante. A miserabilidade da victima, embora possuam ella e sua mãe alguns bens. está corroborada por attestado de auctoridade competente; e 0 artigo 108 da Constituição cogita apenas da aptidão para ser eleitor. Não se refere o preceito invocado á maioridade civil, conforme bem decidiu esta Camara, em accordam de 14 de fevereiro do corrente anno, no recurso crime n. 6.895, de Taubaté (Diario da Justiça de 14 de março de 1935, pag. 21). Continua em vigor, para os effeitos da legislação civil e penal, de accordo com 0 art. 187 da nova Constituição, a regra segundo a qual termina aos 21 annos completos a menoridade. São Paulo, 13 de abril de 1935. - Sylvio Portugal, Presidente e relator; Theodomiro de Toledo Piza; Theodomiro Dias; Arthur de Almeida. (4).

(4) Vide Diario Official do Estado de S. Paulo, de Quinta-Feira, 9 de Maio de 1935. Pag. 26. 
TRABALHO DE SEMINARIO 


\section{TRABALHO DE SEMINARIO}

Apresentada esta these ao Exmo. Snr. Professor Doutor Honorio Fernandes MonteIRo, foi posta em discussão pelo eminente Cathedratico da nossa Faculdade de Direito, em aula de SEMINARIO.

Ás objecções então formuladas, demos immediata resposta.

Reproducção, por escripto, das questões formuladas e réplica nossa no momento - são as linhas abaixo.

1. QUAL A INTELLIGENCIA DO DECRETO N. 20.330 DE 27 DE AGOSTO DE 1931? - NÃO DETERMINA ELLE QUE CESSA A INCAPACIDADE DOS MENORES QUE TENHAM 18 ANNOS CUMPRIDOS?

2. CONCILIA-SE O PÁTRIO PODER COM O EXERCICIO DO VÓTO PELO MENOR? - NÃO PODERIA HAVER COACÇÃO PATERNA?

1. QUAL A INTELLIGENCIA DO DECRETO N. 20.330 DE 27 DE AGOSTO DE 1931? - NÃO DETERMINA ELLE QUE CESSA A INCAPACIDADE DOS MENORES QUE TENHAM 18 ANNOS CUMPRIDOS? - Expedindo o Chefe do Governo Provisorio da Republica dos Estados Unidos do Brasil o decreto $n .^{\circ} 20.330$, de 27 de Agosto de 1931, que introduziu um paragrapho ao artigo $9 .^{\circ}$ do Codigo Civil, patente se tornou pelos seus "consideranda" os motivos que o determinaram e os objectivos visados. 
Qual o texto desse decreto?

Vejamol-o :

DECRETO N. 20.330 - DE 27 DE AGOSTO DE $1931{ }^{(*)}$

Introduz um paragrapho ao art. $9 .^{\circ}$ do Codigo Civil

O Chefe do Governo Provisorio da República dos Estados Unidos do Brasil:

Considerando :

Que o Supremo Tribunal Federal, em varias decisões de "habeas-corpus", tem julgado nullo o alistamento das pessoas de menor idade;

Que ha toda conveniencia em se proceder ao alistamento e sorteio militar dos que completarem 18 annos de idade afim de que possam ser encorporados logo que attinjam a maioridade;

Que as decisões daquella Alta Côrte de Justiça se baseam na incapacidade do menor;

Decreta :

Artigo Unico. a) o paragrapho unico do art. 9. do Codigo Civil passará a ser $\left.\S 10^{\circ} ; b\right)$ ao art. $9 .^{\circ}$ acrescente-se o $\S 2 .^{\circ}$ redigido assim: Para effeito do alistamento e do sorteio militar cessará a incapacidade do menor que houver completado 18 annos de idade.

Rio de Janeiro, 27 de Agosto de 1931, 110. ${ }^{\circ}$ da Independencia e $43 .^{\circ}$ da República.

\author{
Getulio Varaas \\ Oswaldo Aranha \\ Protogenes Guimarães \\ José Fernandes Leite de Castro
}

(*) Vide: Coleção das Leis da Republica dos Estados Unidos do Brasil, Vol. II. "Atos do Governo Provisorio". Maio-Agosto, pag. 681. Indicação Bibliographica da Bibliotheca da Faculdade de Direito de São Paulo: N1 $-22-17$. 
Com a introducção do novo paragrapho, como deverá ser reàigido o art. 9. ${ }^{\circ}$ do Codigo Civil?

Do modo seguinte:

\section{CODIGO CIVIL}

ART. 9. - Aos vinte e um annos completos, acaba a menoridade, ficando habilitado o individuo para todos os actos da vida civil.

$\S 1 .^{\circ}$. Cessará, para os menores, a incapacidade :

I. Por concessão do pae, ou, se fôr morto, da mãe, e por sentença do juiz, ouvido o tutor, se o menor tiver dezoito annos cumpridos.

II. Pelo casamento.

III. Pelo exercicio de emprego publico effectivo.

IV Pela collação de grau scientifico, em curso superior.

$\nabla \quad$ Pelo estabelecimento civil ou commercial, com economia propria.

$\S 2 .^{\circ}$. Para effeito do alistamento e do sorteio militar cessará a incapacidade do menor que houver completado 18 annos de idade.

Portanto :

Dos termos explicitos do decreto $\mathrm{n}^{\circ} 20.330$ resulta:

PRIMUS: Que o processo de alistamento e sorteio militar dos que completavam 18 annos de idade, afim de que pudessem ser encorporados logo que attingissem a maioridade, era inteiramente annullado pelas decisões do Supremo Tribunal Federal cujos accordams se baseavam na incapacidade do menor;

SECUNDUS: Que se o alistamento das pessôas de menoridade era julgado nullo por aquella Alta Côrte de Justiça - o mesmo não haveria de succeder, se PARA EFFEITO DO ALISTAMENTO E DO SORTEIO MILITAR CESSASSE A INCAPACIDADE DO MENOR QUE HOUVESSE COMPLETADO 18 ANNOS DE $I D A D E$; 
TERCIUS: Que o dispositivo legal estatuindo, de maneira RESTRICTIVA, “id est”, DETERMINANDO CLARAMENTE a cessação da incapacidade unicamente para effeito do alistamento e do sorteio militar - poderemos, no caso vertente, applicar, de accordo com as regras da hermeneutica, o argumento a contrario, á disposição analysada acima, que poderá ser ennunciada da seguinte fórma:

\footnotetext{
"Para todos os effeitos, QUE NÃO OS DO ALISTAMENTO E DO SORTEIO MILITAR, não cessará $a$ incapacidade do menor, que houver completado dezoito annos de idade".
}

Donde: SÓ - E TÃO SÓ - PARA EFFEITO DO ALISTAMENTO E DO SORTEIO MILITAR cessa a incapacidade do menor.

O que equivale dizer :

PARA OUTROS EFFEITOS NÃO CESSA A INCAPACIDADE DO MAIOR DE 18 ANNOS E MENOR DE 21 ANNOS: Isto é, a capacidade, no caso previsto pelo decreto n. 20.330, não visa emancipar o menor para EFFEITOS OUTROS DA VIDA CIVIL; visa APENASMENTE, UNICAMENTE - EVITAR QUE O SUPREMO TRIBUNAL FEDERAL JULGASSE NULLO O ALISTAMENTO DAS PESSOAS DE MENORIDADE.

Do que precede, a conclusão logica é a de que - para OUTROS EFFEITOS DA VIDA CIVIL, o menor, que haja completado 18 annos (julgado $C A P A Z$ para effeito do ALISTADENTO e do SORTEIO MILITAR) CONTINÚA IN CAPAZ. O decreto n. ${ }^{\circ}$ 20.330 veiu unicamente DIMINUIR A INCAPACIDADE RELATIVA, ou por outras palavras, o decreto n. 20.330 veiu unicamente AUGMENTAR A CAPACIDADE RELATIVA DOS MAIORES DE 18 ANNOS E MENORES DE 21 ANNOS, dando-lhes capacidade para c effeito do alistamento e do sorteio militar. Donde se conclue que o inciso I do art. 6. ${ }^{\circ}$ da Parte Geral do Codigo Civil deverá ser entendido do modo que se segue: 


\section{CODIGO CIVIL}

Art. $60^{\circ}$ - São incapazes, relativamente a certos actos (art. 147, n. 1), ou á maneira de os exercer:

I. Os maiores de dezeseis e menores de vinte e um annos (arts. 154 e 156), SENDO QUE OS MAIORES DE DEZOITO ANNOS E MENORES DE VINTE E UM ANNOS SAOO CONSIDERADOS CAPAZES PARA EFFEITO DO ALISTAMENTO E DO SORTEIO MILITAR.

Aliás o Codigo Civil firmou de um modo expresso o adagio “EXCEPTIO STRICTISSIMI JURIS" - em o artigo 6. ${ }^{\circ}$ da Introducção, assim redigido:

\section{CODIGO CIVIL - "INTRODUCÇÃO"}

Art. $6 .^{\circ}-\mathrm{A}$ lei que abre excepção a regras geraes, ou restringe direitos, só abrange os casos, que especifica.

Entre outras, EXCEPCIONAES se dizem as disposições (estejam contidas em repositorios de Direito commum, ou se encontrem nos de Direito Especial) que restringem ou condicionam o gozo, ou o exercicio dos direitos civis ou politicos e as que introduzem excepções, de qualquer natureza, a regras geraes, ou a um preceito da mesma lei, A FAVOR, OU EM PREJUIZO, de individuos ou classes da communidade (*).

EXCEPCIONAL não poderá deixar de ser, conseguintemente, a disposição consubstanciada no Decreto n. 20.330, de 27 de agosto de 1931.

\section{CONCILIA-SE O PÁTRIO PODER COM O EXERCICIO DO VOTO PELO MENOR? - NÃO PODERIA HAVER COAC-} ÇÃO PATERNA? - "Coacção" é o estado de quem está coacto.

(*) Vide: CaRlos Maximiliano, Hermeneutica e applicação do direito, 2. ${ }^{\mathrm{a}}$ Ed., 1933, n. 275, pag. 248; DOMAT, "Theoria da Interpretação das leis", Trad. CoRRÊA Telles, "in" Codigo Filipxino, de Candido 
Ora, o que é o voto secreto?

O systema do voto secreto - diz-nos o Professor Doutor Sampaio Doria - consiste em um conjuncto de medidas, graças ás quaes ninguem póde saber em quem o eleitor vóta.

A liberdade de consciencia civica - ensina, ainda, o grande constitucionalista brasileiro - é a alma do voto, e é a pureza das democracias. Logo não se comprehende voto intelligente sem as garantias effectivas desta liberdade.

Ora, o Coligo Eleitoral - Lei n. 48 de 4 de maio de 1935 (*) - (Parte Quinta: Disposições Communs, Titulo I: Das garantias

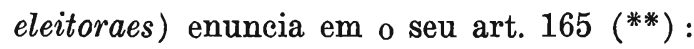

Art. 165. - Serão assegurados aos eleitores os direitos e garantias ao exercicio do voto, nos termos seguintes:

1) Ninguem poderá impedir ou embaraçar o exercicio do suffragio.

Do exposto resulta que a coacção de pae em relação ao filho, para fins eleitoraes, NORMALMENTE, não existe. Somente como excepção poderia ser admittida. E' a regra geral, porém, que nos interessa. E a regra geral é que dentro dos lares brasileiros a educação civica e a educação moral, tocante aos subídos interesses de nossa cara Patria - robustecidas se encontram.

Mendes de Almeida; Emilio CaLdara, Interpretazione delle Leggi, 1908, ns. 167, 206 e 208; Francesco DEGNI, Interpretazione della Legge, 1909, pag. 38 .

(*) Vide Diario Official dos Estados Unidos do Brasil, Anno LXXIV - $47 .^{\circ}$ da Republica - N. 106 - Capital Federal, Quarta-feira, 8 de maio de 1935 , pags. 9081 - 9098.

(**) Quaesquer violencias contra essas garantias de que gozam os cidadãos acham-se precavidas na Lei n. 48 com severissimas comminações: Vejam-se os arts. $82 ; 83$, ns. 1 e $2 ; 183$, ns. $1,2,24,25,28,29,33$ e 34 ; e 184 e seus $\S \S$. 
Mas, se levar fossemos a questão para esse terreno: que série enorme de coacções existiriam!

"Verbi gratia":

I. A coacção do pae em relação ao filho: mas não sómente a coacção em relação ao filho maior de 18 annos e menor de 21 annos, como, tambem, em relação aos maiores de 21 annos - tivessem estes a idade de Mathusalém.

II. A coacção do patrão em relação ao famulo.

III. A do sacerdote em relação ao crente.

IV A do marido em relação á mulher.

A critica que, com estes argumentos, viesse combater o magnifico systema inaugurado, entre nós, a 3 de maio de 1933, seria improcedente e não encontraria o apoio legal.

A coacção paterna para fins eleitoraes é, pois, um mytho.

Não procede o argumento dos que consideram incompativel com o exercicio do voto, a submissão de certos eleitores ao patrio poder. Se é verdade que no decurso da menoridade falta ao sêr humano a capacidade indispensavel para prover ás suas necessidades e reger sua pessôa e bens, - não menos verdade é que esse poder se refére, unica e naturalmente, ao direito civil. Ora, nós já demonstrámos que a capacidade civil é differente da capacidade politica, e que differentes são, tambem, os direitos civis dos direitos politicos. Logo, o argumento não procede: JUSTAMENTE POR ESSE MOTIVO $E$ QUE DISSEMOS ATRAZ QUE A CHAVE DO PROBLEMA RESIDIA NESSA DISTINCCÃO ENTRE CAPACIDADE CIVIL $E$ CAPACIDADE POLITICA, $E N T R E$ DIREITOS CIVIS $E$ DIREITOS POLITICOS. 